\title{
Therapeutic Vaccines Against Human Papillomavirus and Cervical Cancer
}

\author{
Angel Cid-Arregui* \\ Translational Immunology Unit, German Cancer Research Center (DKFZ), Im Neuenheimer Feld 580, D-69120 \\ Heidelberg, Germany
}

\begin{abstract}
Cervical cancer and its precursor intra-epithelial lesions are linked to infection by a subset of so-called "highrisk" human papillomavirus types, which are estimated to infect nearly four hundred million women worldwide. Two prophylactic vaccines have been commercialized recently targeting HPV16 and 18, the most prevalent viral types found in cervical cancer, which operate through induction of capsid-specific neutralizing antibodies. However, in patients with persistent infection these vaccines have not been found to protect against progression to neoplasia. Attempts are being made to develop therapeutic vaccines targeting nonstructural early viral proteins. Among these, E6 and E7 are the preferred targets, since they are essential for induction and maintenance of the malignant phenotype and are constitutively expressed by the transformed epithelial cells. Here are reviewed the most relevant potential vaccines based on HPV early antigens that have shown efficacy in preclinical models and that are being tested in clinical studies, which should determine their therapeutic capacity for eradicating HPV-induced premalignant and malignant lesions and cure cervical cancer.
\end{abstract}

Keywords: HPV, cervical cancer, therapeutic vaccine, immunotherapy.

\section{INTRODUCTION}

Carcinoma of the uterine cervix, or cervical cancer $(\mathrm{CxCa})$, is the second most frequent cause of death by neoplasia in women worldwide with half a million new cases and nearly 300,000 deaths every year [1,2]. About 60,000 new cases of invasive $\mathrm{CxCa}$ and 30,000 deaths are estimated yearly in European countries (including the Russian Federation) [3]. The American Cancer Society estimates that in 2008, nearly 11,000 women will be diagnosed with cervical cancer in the United States, and approximately 4,500 deaths are expected $[4,5]$. Before the vaccine era it was estimated that towards the middle of this century the global incidence of $\mathrm{CxCa}$ might be one million cases per year with an approximate average mortality of $40 \%$ [6]. It is still not known whether the two prophylactic vaccines targeting HPV16 and 18, the most prevalent viral types found in cervical cancer, will help reduce $\mathrm{CxCa}$ morbidity and mortality since their efficacy in the long term has not been assessed yet [7].

HPV belongs to a genus in the Papovavirus family [8] consisting of non-enveloped DNA viruses (Fig. 1) characterized by a strict epithelial tropism and their capacity to induce epidermal proliferation. A subset of these viruses, known as high-risk HPVs (HR-HPVs), has been linked to $\mathrm{CxCa}$ through epidemiological and experimental studies [9]. These have been limited by the strict species specificity of HPVs and their incapacity to propagate in vitro by conventional methods, although the latter was overcome

*Address correspondence to this author at the Translational Immunology Unit, German Cancer Research Center (DKFZ), Im Neuenheimer Feld 580, D-69120 Heidelberg, Germany; E-mail: a.cid@dkfz.de recently by transfection of codon-optimized HPV capsid genes [10]. The oncogenic ability of HR-HPV has been shown by molecular studies in vitro [11], and in transgenic mice $[12,13]$. The HPV genome is a circular DNA molecule of about 8,000 base pairs (Fig. 2, right), which contains a long control region and up to eight open reading frames encoding non-structural and capsid proteins (Table 1). E1, $\mathrm{E} 2$ and $\mathrm{E} 4$ are indispensable for viral replication, regulation of transcription and genome amplification, respectively. E5, E6 and E7 have transforming functions such as activation of the epidermal growth factor receptor and the PI3/Akt pathway, promotion of $\mathrm{p} 53$ degradation and inactivation the retinoblastoma protein $(\mathrm{pRb})$, respectively (see [14] for a review).

The life cycle of HR-HPV is tightly linked to differentiation of the cervical epithelium beginning with the infection of basal cells most likely through negligible lesions (Fig. 2, left) [15]. In the infected basal cells the viral genome persists episomally and is transcribed into a bicistronic message that encodes the early E6 and E7 proteins, which promote cellular proliferation. As these cells migrate towards upper epithelial layers and differentiate, expression of E6 and E7 is switched off and new transcripts are released encoding proteins required for viral genome amplification, most notably E4. Finally, a number of the E4-expressing cells synthesize the capsid proteins L1 and L2, required for assembly of infectious viral particles. In some cells, however, productive infection is aborted and the viral DNA may integrate into the host genome from where the E6 and E7 genes are constitutively transcribed. Continuous expression of E6 and E7 proteins causes cellular transformation leading to increasingly severe epithelial lesions known as cervical intraepithelial neoplasia (CIN), which may eventually progress to invasive cervical cancer. 


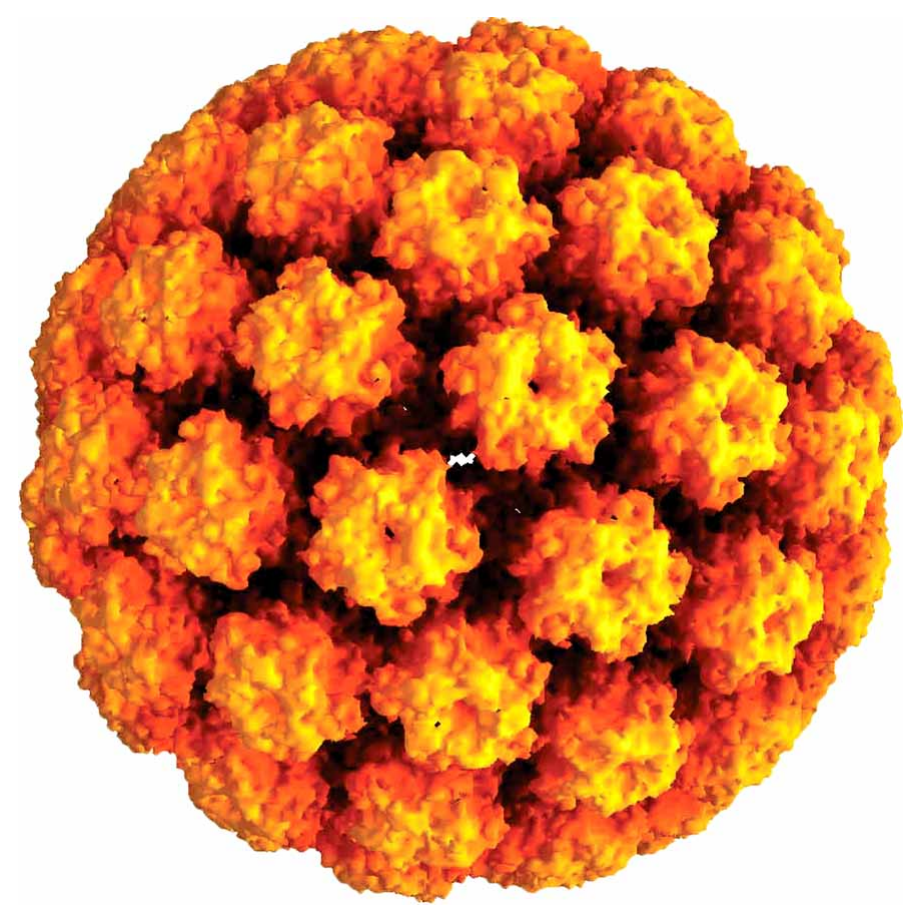

Fig. (1). Computer generated image of a virus-like particle of HPV type 16 [125] (Courtesy of Dr. Jean_Yves Sgro, http://www.virology. wisc.edu/virusworld/viruslist.php?virus=hpv).



epithelium
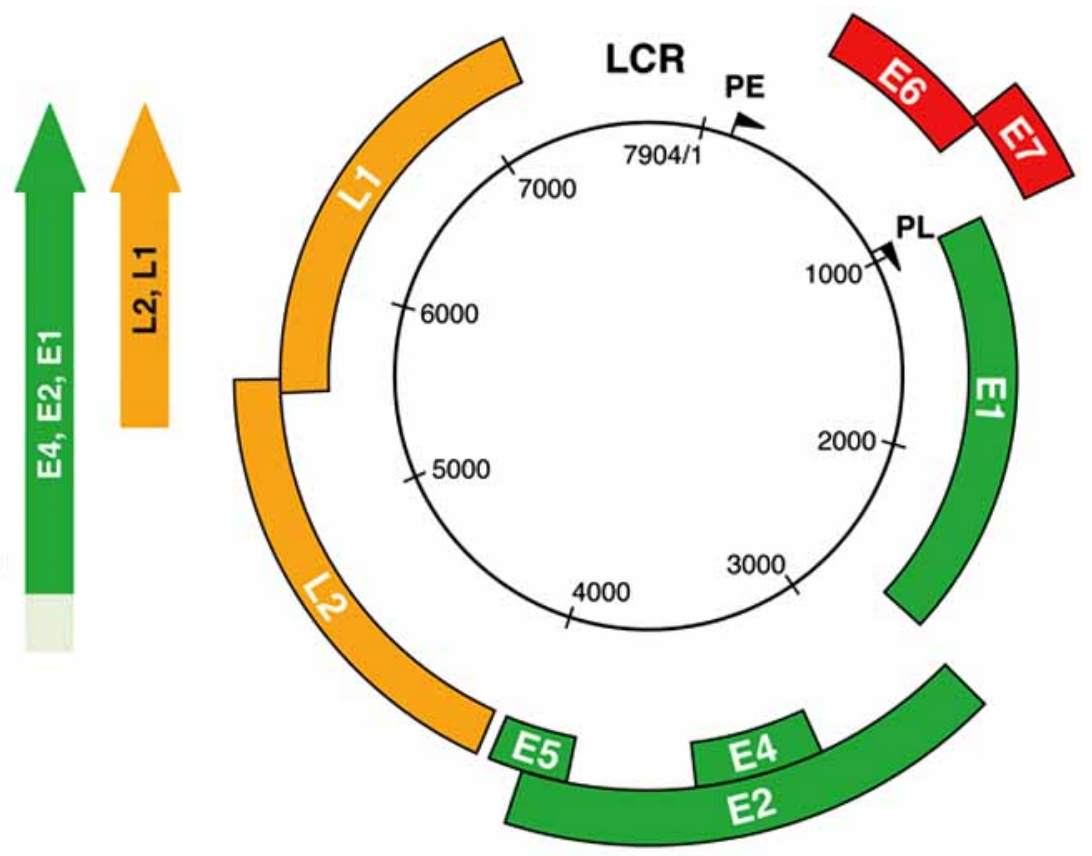

HPV

Fig. (2). Organization of the HPV genome and sequence of viral gene expression along keratinocyte differentiation in the cervical stratified epithelium. Initially, HR-HPVs infect basal keratinocytes. The viral genome resides in the nuclei of basal cells as a low-copy plasmid, which expresses its early genes at very low levels. The E6 and E7 proteins cause up-regulation of cellular proteins necessary for entry into S-phase. As the infected basal cells migrate towards the epithelial surface, the late promoter becomes activated and drives expression of proteins necessary for viral genome amplification (E4). Only a subset of E4(+) cells express the L1 major and minor L2 capsid proteins, allowing packaging of viral genome into infectious particles. During cancer progression, the normal papillomavirus life cycle is disrupted and virus particles are not produced. This represents an abortive infection for the virus. In high-grade cervical neoplasia, cells expressing the viral E7 protein can be found close to the epithelial surface. Expression of the E4 protein and the onset of viral genome amplification do not occur. (Slightly modified from J Doorbar, with permission) [15]. 
Table 1. Proteinsencoded by HR-HPV and Known Functions for Them

\begin{tabular}{|c|c|}
\hline Gene & Function \\
\hline \hline E1 & Initiation of DNA replication \\
\hline E2 & Transcriptional regulation/DNA replication \\
\hline E3 & Cytoskeleton disruption? \\
\hline E4 & Transforming protein, binds to pRB \\
\hline E5 & Transforming protein, interacts with growth factor receptors \\
\hline E6 & Transforming protein, binds to p53, leading to degradation \\
\hline E7 & Major capsid protein \\
\hline E8 & Minor capsid protein \\
\hline L1 & \\
\hline L2 & \\
\hline
\end{tabular}

More than $100 \mathrm{HPV}$ types have been identified to date, of which about 30 have genital tropism. These have been divided into two groups according to their prevalence in genital tumors: 1) "Low-risk" HPV, associated benign lesions such as condiloma, the most frequent types being HPV 6 and 11, but including also the types 40, 42-44, 54, 61, 70, 72 and 81; and 2) "High-risk" HPV, which are involved in the etiology of cervical cancer, including HPV types 16, 18, 31, 33, 35, 39, 45, 51, 52, $56,58,68,73,82$, as demonstrated by epidemiological studies $[16,17]$. HPV16 is the most prevalent HPV type, found in approximately $50 \%$ of $\mathrm{CIN}$ and $\mathrm{CxCa}$ cases, followed by HPV18, 31 and 45 which account for an additional $30 \%$. Infection by high-risk HPV is very frequent among sexually active women, with an incidence of $15-40 \%$ [18]. It has been estimated that by the age of 50 years at least $80 \%$ of women have encountered a high-risk HPV infection at some point of their lives, which makes HPV the most common sexually transmitted agent. Follow-up studies have shown that in $90 \%$ of cases HPV infection is cleared [4]. However, in the remainder $10 \%$ the infection persists more than two years and these women are at high risk of developing $\mathrm{CxCa}[1,19,20]$.

The incidence of $\mathrm{CxCa}$ in developed countries decreased significantly since the introduction of cytological screening programs. Unfortunately, developing countries cannot afford such programs. The recent commercialization of prophylactic HPV vaccines has opened new hopes for the eradication of at least part of the HPV-associated diseases. These vaccines are based on the major capsid proteins (L1) of the most prevalent HPV types. However, women already infected by these HPV types cannot benefit from such vaccines and are at risk of developing $\mathrm{CxCa}$. Given the high mortality rate of invasive $\mathrm{CxCa}$, further investigation to develop immunotherapeutic approaches is needed. Here we review the most relevant aspects of the immune response to HPV in $\mathrm{CIN}$ and $\mathrm{CxCa}$ and the clinical studies applying current therapeutic vaccine strategies against neoplasia associatedwith HPV.

\section{INNATE AND ACQUIRED IMMUNE RESPONSES TO HPV}

Persistence of HPV infection is the consequence of the failure of the host immune system to eliminate the infected cells. This may be due to the fact that HPV propagate without causing neither lysis of keratinocytes nor viremia. Besides, a local immunosuppressive tendency associates with HPV lesions and surrounding tissues, so that no inflammatory response is observed [21]. This has been attributed to the capacity of the viral proteins, in particular E7, to induce tolerance $[22,23]$. According to this, dendritic cells (DCs) infiltrating the epithelial layers (Langerhans cells) loaded with E7 protein from apoptotic tumor cells would not be able to mature and would induce tolerance rather than cytotoxic responses. Moreover, continuous expression of E7 in CIN lesions during years would favor its presentation as autoantigen. Further, the low expression level of E7, in part due to the biased codon usage of the viral genome [24] might facilitate tolerance to this protein.

A number of observations indicate that HPVs have evolved mechanisms to evade the host immune system: 1) E7 of HPV 16 has a high degree of homology with several human proteins [25], which might facilitate recognition as self. 2) E6 and E7 downregulate expression of interferonresponsive genes in infected keratinocytes [26]. HPV 16 E7 abrogates the antiviral effects of interferon-alpha (IFN- $\alpha$ ) [27]. Further, E7 interacts with the interferon regulatory factor IRF-1 and inhibits the IRF-1-mediated activation of the IFN- $\beta$ promoter [28]. E6 and E7 inhibit IL-18-induced IFN- $\gamma$ in natural killer (NK) cells [29]. 3) Extracellular E7 protein inhibits $\mathrm{T}$ cell responses [30]. 4) E6 reduces expression of IL-18 CD8+ [31]. 5) E5 inhibits the acidification of endosomes in keratinocytes and may interfere with proper antigen presentation [32]. 6) HLA expression is altered in cervical neoplasia $[33,34]$ and this may be coupled with defectsin antigen processing. For instance, reduced expression of HLA and the transporter proteins TAP1 and TAP2 has been described in cervical carcinomas [35]. 7) NKG2D-expressing NK and T cells are diminished in $\mathrm{CxCa}$ patients, who also have increased serum levels of soluble MICA (major histocompatibility complex class I-related chain A), a ligand of the NKG2D activating receptor [36]. 8) Langerhans cells are not activated by HPV capsids devoid of genetic material, the so-called virus-like particles (VLPs) [37]. 9) Expression of the chemokine CCL20, which stimulates infiltration of immature LC in the squamous epithelium of the cervix, is altered in HPVtransformed keratinocytes and could be restored by silencing HPV16 E6 and E7 expression by RNA interference [38]. 10) Experimental work with transgenic mice has shown that expression of HPV 16 E7 under control of the keratin 14 promoter in the basal cells of the epidermis causes tolerance [39].

In spite of the ability of HPV to escape immunosurveillance, HPV infection frequently evokes discrete humoral and cellular immune responses [40]. Serological studies based on VLPs indicate that in $50 \%$ of cases the infection with HPV causes a humoral response ( $\mathrm{IgG})$ against specific antigenic regions (conformational epitopes) of the major capsid protein (L1), which correlates with the presence of viral DNA in the cervical smear [41]. In the remaining 50\% the infection disappears leaving behind no detectable antibody response. Neutralizing antibodies are found during regression of lesions induced by HPV. Further, an antibody response against $\mathrm{E} 7$ is observed in a high percentage of CIN and $\mathrm{CxCa}$ cases $[42,43]$. 


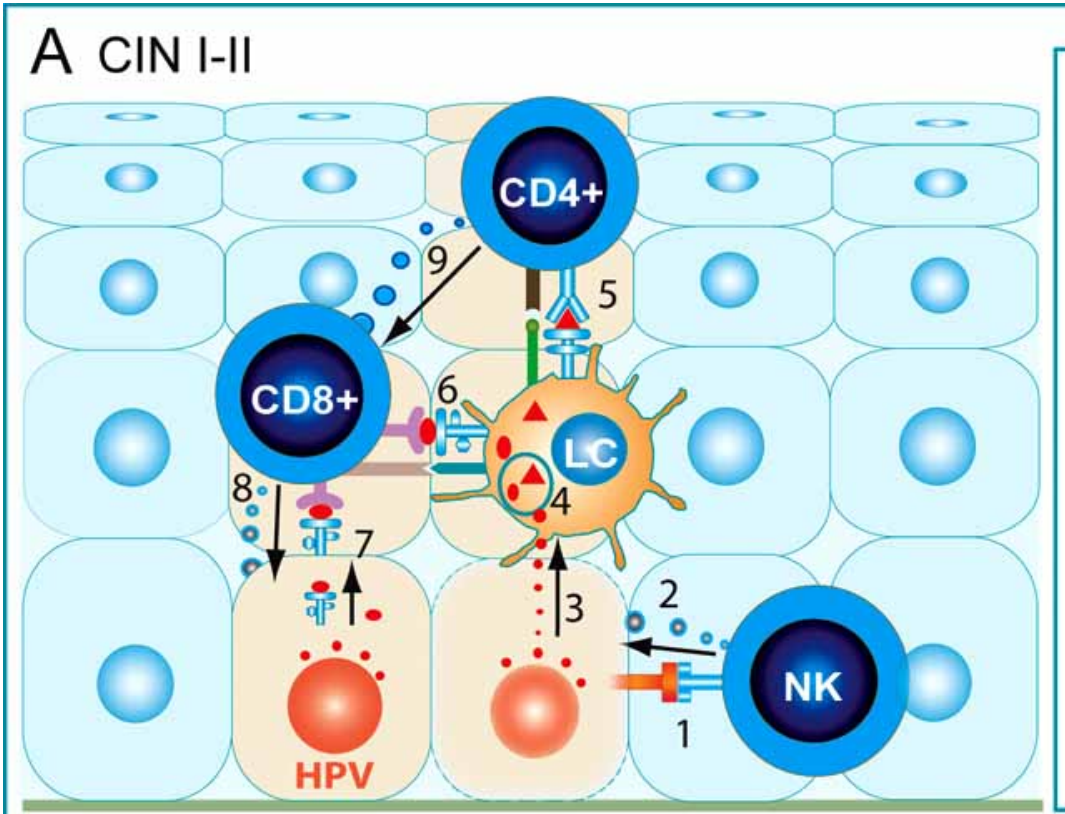

Box 1

Eradication of HPV-infected cells: Regression to normal

- Low level HPV early gene expression

- HPV proteins do not interfere with keratinocyte differentiation

- Normal HLA expression and proper antigen presentation

- Intact cytokine signaling

- Functional Langerhans cells

- Functional NK T cellss

- Activated CD8+ T cells

- Activated CD4+ T cell

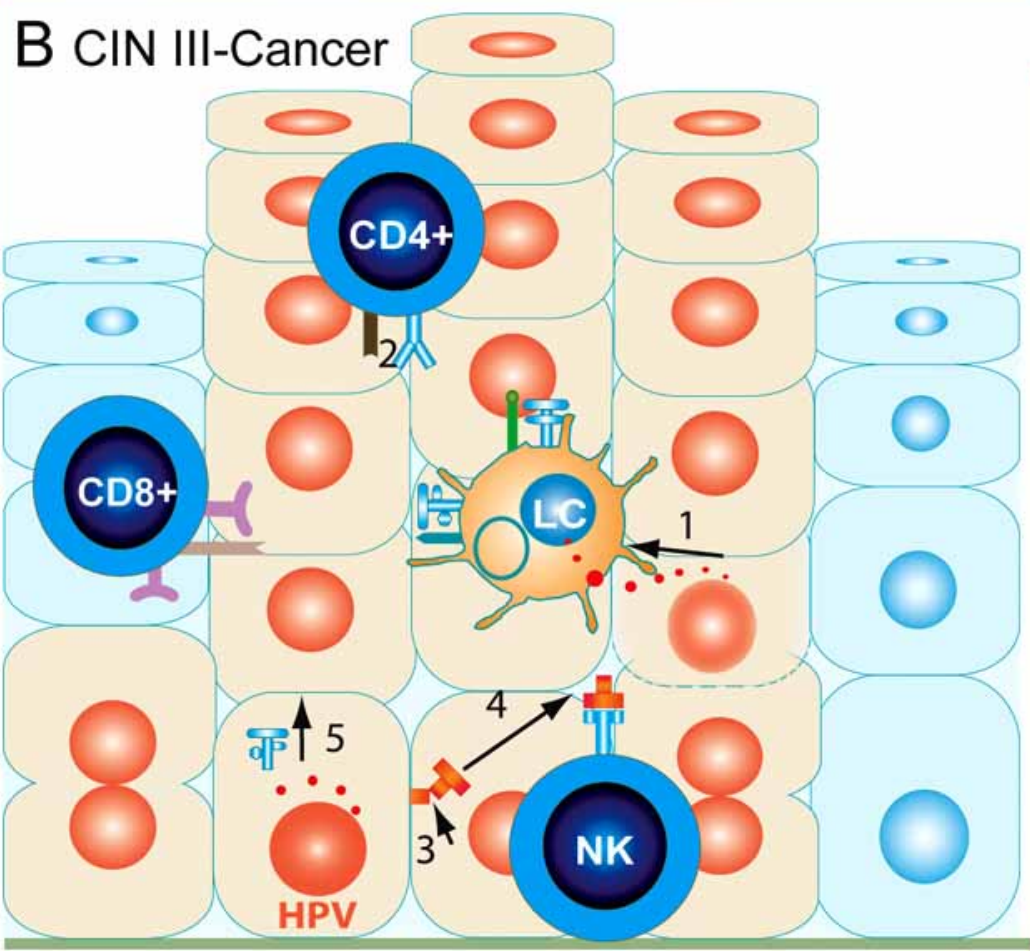

Box 2

Persistent HPV infection, transformation: Progression to cancer

- Constitutive HPV early gene expression

- HPV E6, E7 proteins interfere with keratinocyte differentiation

- LCs loaded with E7 unable to mature induce tolerance

- E6, E7 downregulate IFN-responsive genes

- Disfunctional APCs (Langerhans cells)

- E5 interferes with proper antigen processing

- HPV interference with HLA expression

- Interference with NK cell sigaling: MICA/B shedding on the surface of tumor cells

Fig. (3). Schematic representation of the cellular immune responses to keratinocytes infected by HR-HPVs in pre-cancer and cancer lesions of the uterine cervix. A, CIN I and II pre-cancer lesions usually regress spontaneously as result of effective innate and adaptive cytotoxic responses. Intraepithelial NK cells become activated by ligands of the NKG2D receptor (1), such as the MHC class I-related molecules A and B (MICA and MICB), expressed on the surface of HPV-infected cells, and release the contents of cytolytic granules (2) on the target cell. LCs are intraepithelial professional presenting cells, which take up viral antigens (3) released by apoptotic HPV-infected cells, and subsequently present viral epitopes (4) to CD4+ (5) and CD8+ T cells (6), which become activated. Upon recognition of HPV antigens presented by MHC class I molecules on the surface of HPV-infected cells (7), activated CD8+ T cells also release cytolytic granules (8). These granules contain serine proteases called granzymes, which induce programmed cell death in the target cells. Activated CD4 ${ }^{+} \mathrm{T}$ cells secrete cytokines that stimulate cytolytic $\mathrm{CD} 8^{+} \mathrm{T}$ cells (9). Box 1 summarizes the conditions that allow recognition and eradication of HPVinfected cells by the immune cells. B, Advanced cervical CIN III pre-cancer and cancer lesions progress while the effectors of cellular immunity remain passive or unable to eliminate the HPV-infected/transformed cells. LCs loaded with HPV antigens (1) released by HPVinfected cells are unable to mature and cannot present antigen to and activate $\mathrm{CD} 4{ }^{+}$and $\mathrm{CD} 8^{+} \mathrm{T}$ cells. Instead, $\mathrm{CD} 4{ }^{+} \mathrm{FoxP} 3{ }^{+}$regulatory $\mathrm{T}$ cells infiltrate the lesion and down-regulate effector T lymphocytes. Further, NKG2D-ligands on the surface of infected cells undergo cleavage and their ectodomains are released (2) as soluble molecules that bind NKG2D on NK cells (3), which thereby become inactive (4). In addition, antigen presentation is altered (5). The mechanisms used by HPV to evade immunosurveillance are listed in Box 2. 
Nevertheless, a number of observations indicate that cellular responses against HPV are relevant for eradication of established infection: 1) humoral immunodeficiency does not predispose to the development of precancerous lesions associated with HPV infection [44]. 2) Patients with reduced $\mathrm{CD} 4+\mathrm{T}$ cell function, such as transplanted patients and those infected by the HIV, present a higher prevalence of infection by HPV and associated CIN lesions. 3) Spontaneous regression of CIN lesions is accompanied by a delayed hypersensitivity response mediated by $\mathrm{CD} 4+\mathrm{T}$ cells infiltrating the infected epithelium. 4) Cervical tumors contain functionally altered DCs [45]. 5) Immunostimulatory signals mediated by cytokines are disabled in these tumors [46]. 6) In patients with CIN persistently infected by HPV16 there is an increase in the frequency of $\mathrm{CD} 4^{+} \mathrm{CD} 25^{\text {hi }}$ regulatory $T$ cells [47], and the lesions are highly infiltrated with $\mathrm{CD} 4^{+} \mathrm{FoxP}^{+} \mathrm{T}$ cells, which are normally absent in the cervical epithelium [48]. This suggests that at least part of the lymphocytes infiltrating the HPV neoplasia can act suppressing anti-tumor immune responses. 7) AIN and VIN patients treated with Imiquimod, an agent that stimulates TLR-7 on APC and induces Th1 cell-mediated immune responses [49], showed specific $\mathrm{CD} 4+\mathrm{T}$ cell responses to HPV 16 correlating with remission of lesions [50-52].

A significant conclusion of the above observations is that studies testing the therapeutic capability of new candidate vaccines should include a careful examination of the patients' immune system before and after vaccination. While humoral immunity generates neutralizing antibodies that protect against initial infection, cell-mediated immunity is indispensable to eradicate persistent HPV infection and stop tumor progression. Further, immunotherapy strategies should include effective in situ modulation of the $\mathrm{CD} 4^{+}$regulatory $\mathrm{T}$ cell activity, which might require the use of adjuvants that generate a convenient cytokine environment at the lesion site. Fig. (4) summarizes the interplay between cellular effectors of the immune system and HPV-infected cells, which might lead to HPV clearance and regression of neoplastic lesions in most cases of CIN I and CIN II or to tolerance and cancer progression in advanced CIN III.

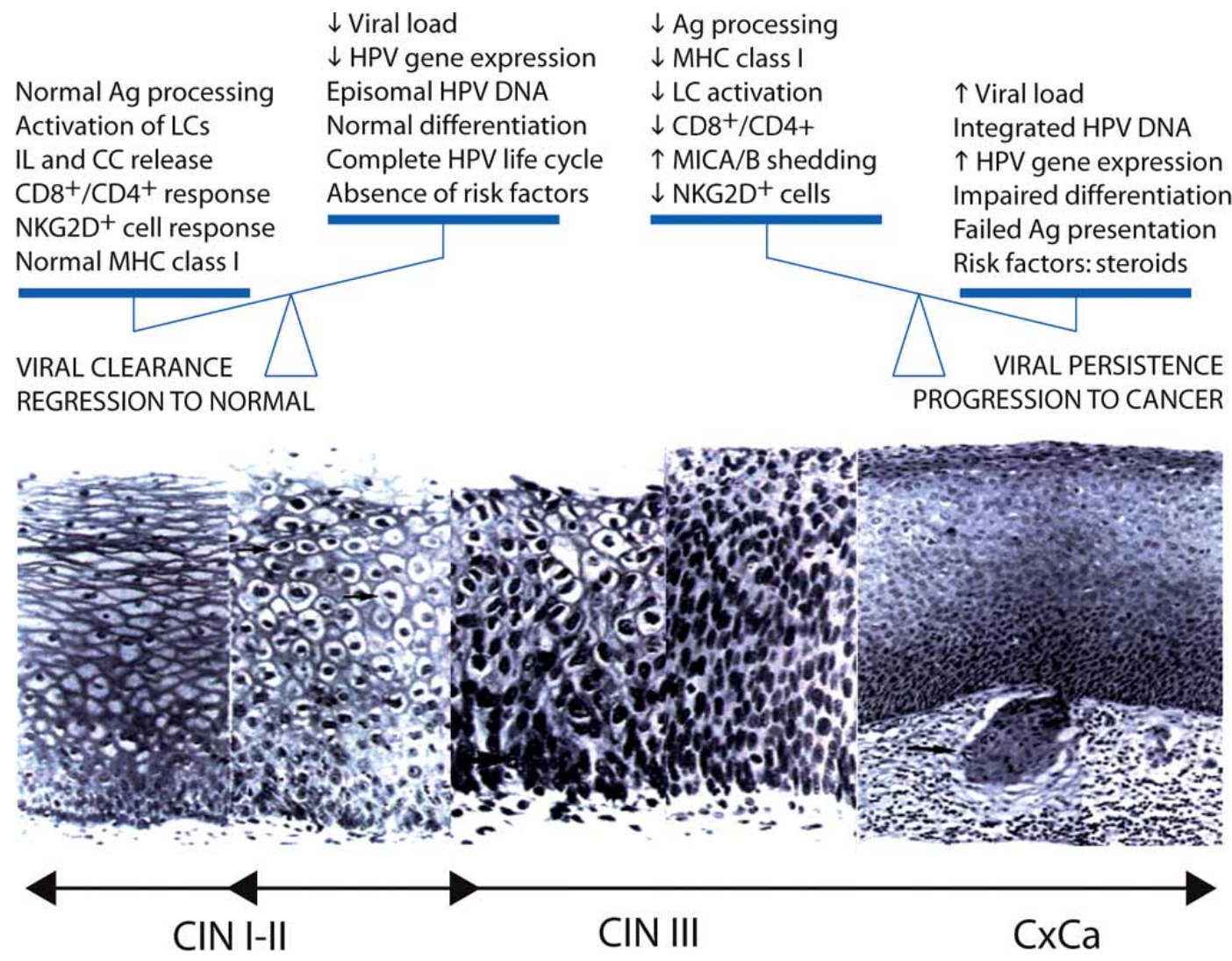

Fig. (4). An imbalance in the interaction between viral and host factors may lead to clearance of infection and regression of lesions caused by HR-HPV or rather to progression to invasive cancer. Most CIN I and CIN II lesions (left side) regress spontaneously. The viral genome remains episomal in the infected keratinocytes and viral load is low as is the expression of viral proteins. Under these conditions, the cells can differentiate, which allows expression of capsid proteins and virus assembly and release. Antigen processing and MHC class I expression remain unaltered. Released viral particles are endocytosed, processed and presented by LCs triggering strong $\mathrm{T}$ cell responses. NK cells become activated through the NKG2D receptor upon binding to MICA/B expressed on the surface of the infected keratinocytes. In contrast, the vast majority of CIN III lesions progress to cancer as result of persistence of viral infection, which leads to integration of the viral DNA into the host genome and enhanced viral gene expression. The E6 and E7 viral products interfere with keratinocyte differentiation, and antigen presentation. MICA/B molecules undergo shedding by proteases released by the transformed cells and the soluble MICA/B-derived polypeptides cause a reduction in the number of $\mathrm{NKG}_{2} \mathrm{D}^{+} \mathrm{NK}$ and $\mathrm{T}$ cells. Some risk factors such as sexual promiscuity, steroid hormones (contraceptives) and smoking may cooperate with the virus by increasing the viral load, enhancing gene expression and the rate of mutagenesis, respectively. 


\section{Tumor-Specific Antigens in HPV Precancerous Lesions and Tumors}

In acute infection by high risk HPVs the expression of E6 and E7 viral genes takes place in the basal layer of the cervical epithelium where they induce up-regulation of cellular proteins that control the cell cycle (Fig. 2). As the infected cells differentiate and migrate to the surface the viral late promoter becomes activated and drives expression of proteins involved in amplification of the viral genome, the most abundant being E4 [53]. A subset of these cells expresses also the L1 and L2 capsid proteins, which assemble with the viral genome to form new infectious viral particles.

During progression towards cervical cancer, the HPV life cycle is disrupted and viral particles are not produced [53]. Thus, in high-grade cervical dysplasia, expression of E4 and viral genome amplification do not occur. Instead, E6 and E7 expression takes place in upper epithelial layers, where these proteins interfere with the regulation of the cell cycle and the formation of the mitotic spindle [54] and leads to histologic aberrations such as anisonucleosis and hyperchromasia. E6 and $\mathrm{E} 7$ are found constitutively expressed in $\mathrm{CxCa}$ as well as derived cell lines, such as HeLa (HPV18), $\mathrm{SiHa}$ and CaSki (HPV16) [9] and therefore, represent tumor-specific antigens (TSAs). Both E6 and E7 from HPV16 and 18 contain epitopes that are presented by HLA-A2 molecules of the MHC class I [55]. Peptides carrying MHC class I restricted epitopes from those proteins have been shown to stimulate cellular immunity in both animal models and humans [55, 56].

Besides HPV proteins there are endogenous proteins expressed abnormally in precancerous and cancerous cervical lesions. Molecular analysis of dysplastic cells found in $\mathrm{CIN}$ and $\mathrm{CxCa}$ lesions has shown a correlation between the lesion grade and the expression of HPV E7 with high levels of $\mathrm{p} 16^{\mathrm{ink} 4 \mathrm{a}}$ [57-59]. This protein is an inhibitor of cyclin-dependent kinases that plays a crucial role in the regulation of the cell cycle. The expression of $\mathrm{p} 16^{\text {ink4a }}$ is tightly regulated in normal cells, which produce very low amounts of this protein that are undetectable by immunohistochemical methods. Along with the transdifferentiation process during HPV-induced squamous metaplasia, the expression of $\mathrm{p} 16^{\text {ink4a }}$ is already enhanced in early lesions [60], and continues progressively rising to the high levels detectable in cells from CIN III and CxCa lesions. Such phenomenon results from the transforming activity of E7 encoded by HR-HPVs, which by inactivating $\mathrm{pRb}$ interferes with the negative feedback that this protein normally exerts on transcription of the $\mathrm{p} 16^{\text {ink4a }}$ gene. Therefore, $\mathrm{p} 16^{\text {ink4a }}$ is not only an indicator of the oncogenic activity of HR-HPVs but also represents a tumor-associated antigen, and hence a possible target for immunotherapy.

\section{Therapeutic HPV Vaccines}

Although prophylactic vaccines are effective in preventing HPV16 and 18 precancerous lesions, and even induce cellular immunity to $\mathrm{L} 1$, recent clinical studies indicate that they have no therapeutic effects [61, 62]. Therefore, women already infected with oncogenic HPVs are at risk of developing cancer. This warrants further development of therapeutic vaccines aimed to induce cellular immune responses against HPV early antigens such as E6 and E7, which unlike capsid antigens are constitutively expressed in HPV precancerous lesions and tumors. These proteins contain antigenic regions that are presented by HLA-A2 molecules and have been shown to be immunogenic in mouse and humans [63]. Immune responses involved in eradication of tumor cells are essentially mediated by $\mathrm{CD} 8+\mathrm{T}$ cells. However, an effective and sustained activity of $\mathrm{CD} 8+\mathrm{T}$ cells requires the collaboration of CD4+ helper T cells (Fig. 3). This section describes the most relevant clinical studies carried out with therapeutic vaccine candidates developed to dateand their reported results (Table 2).

\section{Peptide Vaccines}

Peptide vaccines are simple, well tolerated and easy to produce. The low cost associated with good manufacturing production (GMP) of peptide-based vaccines led many investigators in the past to initiate clinical studies with peptides harboring HLA-A2 epitopes from the E6 and E7 proteins. A phase I clinical study by Steller et al. [64] explored the efficacy of an E7-derived lipopeptide (HPV 16 $E 7^{86-93}$ ) with affinity for HLA-A*0201 molecules, linked to then non-specific pan-HLA DR peptide PADRE, which carries a helper $\mathrm{T}$ cell epítope $[65,66]$. Twelve patients with refractory cervical or vaginal cancer were selected, who received four s.c. doses of the vaccine at three week intervals. E $7^{86-93}$-specific CLT responses, detected by IFN- $\gamma$ release assay, were observed in 5 patients after two doses and in 2 patients after all four immunizations. Nevertheless, no clinical responses were observed in these patients. In a different clinical study of phase I/II two HPV 16 peptides $E 7^{11-20}$ and $E 7^{86-93}$ with high HLA-A*0201 binding capacity were utilized emulsified in incomplete Freund's adjuvant (IFA) in combination with the PADRE helper peptide. A total of 19 HLA-A*0201+ patients were divided into three groups receiving escalating doses of peptide $(100,300$ or $1000 \mu \mathrm{g})$ s.c., four times at three-week intervals [67]. After one-year follow-up two patients showed disease stabilization and two others underwent tumor regression after subsequent chemotherapy treatment, the rest suffered progressive disease. Analysis of PBMCs showed that vaccination did not induce E7 peptide-specific CTL in any of these patients and that part of the patients had a reduced number of lymphocytes, suggesting that the advanced disease in these patients caused immunocompromise.

A similar vaccine was tested in a phase I study on 18 HLAA2 patients with high-grade intraepithelial neoplasia of cervix or vulva positive for HPV16 [68]. The patients were vaccinated with the $E 7^{12-20}$ peptide in IFA and the $E 7^{86-93}$ peptide linked to the PADRE helper peptide and a covalently coupled lipid. The vaccine was administered in four doses at three-week intervals. Three complete and nine partial remissions of the dysplastic lesions were observed. E7 peptide-specific CTL responses were detected in PBMCs from 10 patients. However, delayed type hypersensitivity (DTH) response was not observed in any of the vaccinated patients. Further, in situ RNA hybridizations showed no viral clearance in any of the patients, including those with negative Pap smear. 
Table 2. Clinical Studies with Therapeutic HPV Vaccines

\begin{tabular}{|c|c|c|c|c|c|c|c|}
\hline $\begin{array}{l}\text { Type of } \\
\text { Vaccine }\end{array}$ & Composition / Adjuvant & Via & $\begin{array}{l}\text { Phase of } \\
\text { Study }\end{array}$ & Patients & Immune Response & $\begin{array}{c}\text { Clinical } \\
\text { Response }\end{array}$ & Refs. \\
\hline \multirow{3}{*}{$\begin{array}{l}\text { Peptide } \\
\text { vaccines }\end{array}$} & $\begin{array}{l}\text { HPV-16 E7 }{ }^{86-93} \text { peptide conjugated } \\
\text { with lipid (palmitic acid) linked to } \\
\text { the non-specific PADRE helper } \\
\text { peptide }[65,66]\end{array}$ & $\mathrm{SC}$ & I & $\begin{array}{c}12 \text { patients (HLA- } \\
\text { A*0201) with refractory }^{*} \\
\text { cervical or vaginal } \\
\text { cancer }\end{array}$ & $\begin{array}{l}\text { E7-specific CTL } \\
\text { response in } 7 \text { patients }\end{array}$ & $\begin{array}{l}\text { No clinical } \\
\text { response }\end{array}$ & $\mathrm{a}$ \\
\hline & $\begin{array}{c}\text { Two HPV-16 E7 peptides (E7 }{ }^{12-20} \\
\text { and E7 }{ }^{86-93} \text { ) linked to the non- } \\
\text { specific PADRE helper peptide } \\
\text { Adjuvant: IFA }\end{array}$ & $\mathrm{SC}$ & I-II & $\begin{array}{c}19 \text { cervical cancer } \\
\text { patients }(\text { HLA-A*0201) }\end{array}$ & $\begin{array}{c}\text { No E7-specific CTL } \\
\text { response }\end{array}$ & $\begin{array}{l}2 \text { partial } \\
\text { remissions }\end{array}$ & $b$ \\
\hline & $\begin{array}{c}E 7^{12-20} \text { and } E 7^{86-93} \text { Peptides linked to } \\
\text { the PADRE helper peptide bound } \\
\text { to a lipid radical } \\
\text { Adjuvant : IFA }\end{array}$ & $\mathrm{SC}$ & I & 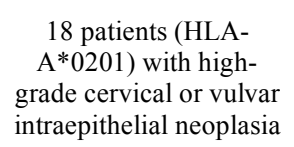 & $\begin{array}{l}\text { E7-specific CTL } \\
\text { response in } 10 \\
\text { patients }\end{array}$ & $\begin{array}{l}3 \text { complete } \\
\text { remissions } \\
9 \text { partial } \\
\text { remissions }\end{array}$ & $\mathrm{c}$ \\
\hline \multirow{5}{*}{$\begin{array}{c}\text { Protein } \\
\text { vaccines }\end{array}$} & $\begin{array}{c}\text { Fusion protein containing HPV-16 } \\
\text { E7 and HSP-65 of Mycobacterium } \\
\text { Bovis BCG }\end{array}$ & $\mathrm{SC}$ & II & $\begin{array}{l}22 \text { anal HSIL patients, } \\
\text { of which } 14 \text { presented } \\
\text { anogenital condiloma }\end{array}$ & Non-determined & $\begin{array}{l}3 \text { complete } \\
\text { remissions } \\
10 \text { partial } \\
\text { remissions }\end{array}$ & $\mathrm{d}$ \\
\hline & $\begin{array}{l}\text { Fusion protein containing HPV-16 } \\
\text { L2, E6 and E7 } \\
(\text { TA-CIN) }\end{array}$ & IM & I & 40 healthy volunteers & $\begin{array}{l}\text { E6 and E7-specific } \\
\text { CTL responses in } 8 \\
\text { patients }\end{array}$ & $\begin{array}{c}\text { Not } \\
\text { determine } \\
\mathrm{d}\end{array}$ & $\mathrm{e}$ \\
\hline & $\begin{array}{c}\text { Three doses ofTA-CIN, followed } \\
\text { by one dose of TA-HPV (see below } \\
\text { Viral Vector Vaccines) } \\
\text { (Prime-boost trial) }\end{array}$ & $\mathrm{IM}$ & II & 29 & & & \\
\hline & $\begin{array}{c}\text { Fusion protein containing HPV-16 } \\
\text { E6 and E7 Adjuvant: } \\
\text { ISCOMATRIX }^{\circledR}[78]\end{array}$ & IM & I & $\begin{array}{c}8 \text { CIN I patients } \\
10 \text { CIN II patients NIC } \\
\text { II } \\
13 \text { CIN III patients }\end{array}$ & $\begin{array}{c}\text { Specific CTL } \\
\text { responses in } 5 \\
\text { patients } \\
\text { Delayed type } \\
\text { hypersensitivity } \\
\text { (DTH) } \\
\text { To E6 and E7 in } 18 \\
\text { patients }\end{array}$ & $\begin{array}{l}4 \text { complete } \\
\text { remissions }\end{array}$ & $\mathrm{f}$ \\
\hline & $\begin{array}{c}\text { Fusion protein containing an HPV- } \\
16 \text { E7 mutant conjugated to the } \\
\text { Haemophilus influenzae protein D } \\
\text { (PD-E7) } \\
\text { Adjuvant: AS02B }\end{array}$ & IM & $\mathrm{I} / \mathrm{II}$ & $\begin{array}{l}5 \text { CIN III patients } \\
2 \text { CIN I patients }\end{array}$ & $\begin{array}{l}\text { Increase of } \\
\text { preexisting cellular } \\
\text { response to PD-E7 in } \\
5 \text { patients }\end{array}$ & $\begin{array}{l}2 \\
\text { remissions } \\
\text { (CIN I } \\
\text { patients) }\end{array}$ & $\mathrm{g}$ \\
\hline \multirow[b]{2}{*}{$\begin{array}{l}\text { Dendritic } \\
\text { cell } \\
\text { vaccines }\end{array}$} & $\begin{array}{l}\text { Autologous DCs loaded with } \\
\text { recombinant HPV-16 or HPV-18 } \\
\text { E7 protein }\end{array}$ & $\mathrm{SC}$ & I & $\begin{array}{l}15 \text { grade IV cervical } \\
\text { cancer patients }\end{array}$ & $\begin{array}{l}\text { CTL responses in } 4 \\
\text { patients } \\
\text { Antibody responses } \\
\quad \text { in } 3 \text { patients }\end{array}$ & No & $\mathrm{h}$ \\
\hline & $\begin{array}{l}\text { DCs loaded with HPV-16 E7 or } \\
\text { HPV-18 } \\
\text { and human recombinant IL-2 }\end{array}$ & $\mathrm{SC}$ & I & $\begin{array}{l}4 \text { cervical cancer } \\
\text { patients }(\mathrm{HPV}-16+\text { or } \\
\text { HPV }-18+) \text { refractory to } \\
\text { standard treatment }\end{array}$ & $\begin{array}{l}\text { Specific antibody and } \\
\text { CD4+ T lymphocytes } \\
\text { in } 2 \text { patients } \\
\text { Increase in E7- } \\
\text { specific CD8+ T cells } \\
\text { in } 4 \text { patients }\end{array}$ & No & $\mathrm{i}$ \\
\hline \multirow{3}{*}{$\begin{array}{c}\text { DNA } \\
\text { vaccines }\end{array}$} & $\begin{array}{c}\text { ZYC101: Zycos } 101 \text { plasmid DNA } \\
\text { encoding several HLA-A2 epítopes } \\
\text { from HPV-16 E7 Encapsulated in } \\
\text { microparticles of biodegradable } \\
\text { polymer }\end{array}$ & IM & I & $\begin{array}{l}12 \text { anal dysplasia } \\
\text { patients }\end{array}$ & $\begin{array}{l}\text { Increased } \\
\text { responses to E7 } \\
\text { epitopes in } 10 \text { cases }\end{array}$ & $\begin{array}{l}3 \text { partial } \\
\text { remissions }\end{array}$ & $\mathrm{j}$ \\
\hline & ZYC101 & $\begin{array}{c}\mathrm{SC} / \\
\mathrm{IM}\end{array}$ & I & 15 CIN II/III patients & $\begin{array}{l}11 \mathrm{HPV} \text {-specific } \\
\text { CTL responses }\end{array}$ & $\begin{array}{l}5 \text { complete } \\
\text { remissions }\end{array}$ & $\mathrm{k}$ \\
\hline & $\begin{array}{l}\text { Amolimogene/ZYC101a: plasmid } \\
\text { DNA encoding fragments from } \\
\text { HPV-16 and } 18 \text { E6 and E7 } \\
\text { Encapsulated in microparticles of } \\
\text { biopolymer }\end{array}$ & IM & II & $\begin{array}{l}127 \mathrm{CIN} \text { II/III patients } \\
\text { (86 under treatment) }\end{array}$ & $\begin{array}{l}80 \text { Increased } \\
\text { preexisting specific T } \\
\text { cell responses }\end{array}$ & $\begin{array}{l}37 \\
\text { complete } \\
\text { remissions }\end{array}$ & 1 \\
\hline
\end{tabular}




\begin{tabular}{|c|c|c|c|c|c|c|c|}
\hline $\begin{array}{l}\text { Type of } \\
\text { Vaccine }\end{array}$ & Composition / Adjuvant & Via & $\begin{array}{l}\text { Phase of } \\
\text { Study }\end{array}$ & Patients & Immune Response & $\begin{array}{l}\text { Clinical } \\
\text { Response }\end{array}$ & Refs. \\
\hline \multirow{8}{*}{$\begin{array}{c}\text { Viral } \\
\text { vector } \\
\text { vaccines }\end{array}$} & $\begin{array}{l}\text { TA-HPV vaccine: vaccinia virus } \\
\text { strain Wyeth encoding a HPV } 16 \\
\text { and } 18 \text { E6/ E7 fusion protein }\end{array}$ & $\begin{array}{l}\text { Dermal } \\
\text { scarific } \\
\text { ation }\end{array}$ & I & $\begin{array}{l}8 \text { advanced cervical } \\
\text { cancer patients (grades } \\
\text { Ib-IIIb or recurrent) }\end{array}$ & $\begin{array}{l}3 \text { humoral responses } \\
\text { against } \mathrm{E} 6 / \mathrm{E} 7 \text {, and } 8 \\
\text { anti-vaccinia } \\
1 \mathrm{HPV} \text {-specific CTL } \\
\text { response }\end{array}$ & No & $\mathrm{m}$ \\
\hline & TA-HPV & $\begin{array}{l}\text { Dermal } \\
\text { scarific } \\
\text { ation }\end{array}$ & I & $\begin{array}{c}29 \text { cervical cancer } \\
\text { patients (grade Ib o IIa) }\end{array}$ & $\begin{array}{c}8 \text { HPV-specific } \\
\text { antibody responses } \\
4 \mathrm{HPV} \text {-specific CTL } \\
\text { responses }\end{array}$ & No & $\mathrm{n}$ \\
\hline & TA-HPV & $\begin{array}{l}\text { Dermal } \\
\text { scarific } \\
\text { ation }\end{array}$ & II & $12 \mathrm{VIN}$ patients & $\begin{array}{c}6 \mathrm{CD} 4+\mathrm{T} \\
\text { lymphocyte } \\
\text { responses } \\
10 \text { HPV-specific } \\
\text { antibody responses }\end{array}$ & $\begin{array}{l}5 \text { partial } \\
\text { remissions } \\
1 \text { complete } \\
\text { remission }\end{array}$ & 0 \\
\hline & TA-HPV & $\begin{array}{l}\text { Dermal } \\
\text { scarific } \\
\text { ation }\end{array}$ & II & $\begin{array}{l}18 \text { high grade VIN } \\
\text { patients }\end{array}$ & $\begin{array}{c}8 \mathrm{~T} \text { cell proliferation } \\
\text { responses } \\
5 \text { INF- } \gamma \text { response } \\
1 \text { humoral response }\end{array}$ & $\begin{array}{l}8 \text { partial } \\
\text { remissions }\end{array}$ & $\mathrm{p}$ \\
\hline & MVA-E2 & $\begin{array}{l}\text { Intra- } \\
\text { uterus }\end{array}$ & I-II & $\begin{array}{l}36 \text { CIN I, II or III } \\
\text { patients }\end{array}$ & $\begin{array}{l}\text { Humoral and cellular } \\
\text { responses in all cases }\end{array}$ & $\begin{array}{c}34 \\
\text { complete } \\
\text { remissions }\end{array}$ & $\mathrm{q}$ \\
\hline & MVA-E2 & $\begin{array}{l}\text { Intra- } \\
\text { uterus }\end{array}$ & II & $34 \mathrm{CIN}$ II or III patients & $\begin{array}{l}\text { Humoral and cellular } \\
\text { responses in all cases }\end{array}$ & $\begin{array}{l}20 \\
\text { complete } \\
\text { remissions } \\
11 \text { partial } \\
\text { remissions }\end{array}$ & $\mathrm{r}$ \\
\hline & $\begin{array}{l}\text { MVA-HPV-IL2: recombinant } \\
\text { Modified Vaccinia Virus Ankara } \\
\text { (MVA), attenuated vaccinia strain, } \\
\text { encoding modified E6 y E7 } \\
\text { proteins and IL-2 }\end{array}$ & IM & II & $31 \mathrm{CIN}$ II/III patients & Not reported & $\begin{array}{l}5 \text { partial } \\
\text { remissions }\end{array}$ & $\mathrm{s}$ \\
\hline & MVA-HPV-IL2 & $\mathrm{SC}$ & II & $21 \mathrm{CIN}$ II/III patients & Not reported & $\begin{array}{l}10 \text { partial } \\
\text { remissions }\end{array}$ & $\mathrm{t}$ \\
\hline
\end{tabular}

Abbreviations: aa: amino acid; IFA: Incomplete Freund's Adjuvant; HPV: Human papillomavirus; IL-2: interleukine-2; IM: Intramuscular; HSIL: high grade squamou intraepitelial lesion; CIN: cervical intraepithelial neoplasia; VIN: Vulvar/vaginal intraepitelial neoplasia; SC: subcutaneous.

$\begin{array}{ll}\text { (a) } & {[64] .} \\ \text { (b) } & {[67,126]} \\ \text { (c) } & {[68] .} \\ \text { (d) } & {[69] .} \\ \text { (e) } & {[75] .} \\ \text { (f) } & {[80] .} \\ \text { (g) } & {[82] .} \\ \text { (h) } & {[87] .} \\ \text { (i) } & {[88] .} \\ \text { (j) } & {[91] .} \\ \text { (k) } & {[92] .} \\ \text { (l) } & {[93] .} \\ \text { (m) } & {[98] .} \\ \text { (n) } & {[99] .} \\ \text { (o) } & {[100] .} \\ \text { (p) } & {[101] .} \\ \text { (q) } & {[102] .} \\ \text { (r) } & {[103] .} \\ \text { (s) } & {[108] .} \\ \text { (t) } & {[115] .}\end{array}$

Altogether, these studies demonstrated that vaccination with peptides even at high doses is well tolerated; yet the immune responses induced were insufficient to induce satisfactory clinical responses. One possible explanation for this may be that in most studies patients with advanced grade cancers were selected, whose immune function was somehow compromised. Nevertheless, new peptide vaccine strategies combining advances in engineering peptides, adjuvants and delivery systemsmight result in efficient antitumor responses [63]. 


\section{Protein Vaccines}

An advantage of protein vaccines is that they harbor numerous CTL epitopes and hence do not require determining the HLA haplotype. During the last years a number of cervical cancer vaccines using modified E6 and E7 proteins from HPV16 have been developed and tested in preclinical and clinical studies. One of these was a fusion protein named HspE7 (Stressgen, San Diego) containing the E7 protein of HPV16 fused to the heat shock protein (Hsp) 65 from Mycobacterium bovis bacillus Calmette-Guerin (BCG), a potent activator of DC and inductor of immune cellular response. In a phase II clinical trial, 22 patients with high-grade anal intraepithelial neoplasia (AIN), positive for HPV16, received three doses of HspE7 vaccine (500 $\mu \mathrm{g} /$ dose, monthly) [69]. The results showed conversion to low-grade AIN in 13 patients within 3-6 months as well as 3 complete remissions. Another study with HspE7 administered to 21 patients with CIN lesions associated with HPV16 led to 8 remissions in two months [70]. A more recent clinical study with the same protein involving 133 patients showed no difference between HspE7 and placebo [71]. Nevertheless, in this study the interpretation of the degree of dysplasia in the lesions by the different pathologists involved varied considerably, indicating that quantitative surrogate parameters such as viral load will need to be evaluated in further trials. In 2006, Stressgen decided not to go into phase III clinical trials with this vaccine arguing that a new formulation combining HspE7 with adjuvant, with which a new phase I trial was to be started [72], seemed to be more effective. This company changed to Nventa Biopharmaceuticals in 2006 andconducted a fourcohort phase I study on healthy volunteers with HspE7 combined with escalating doses of adjuvant containing polyICLC, a toll-like receptor 3 (TLR3) agonist. The results of this study were announced on May 2008 [73]. In the first cohort $(500 \mu \mathrm{g}$ HSPE7 and $50 \mu \mathrm{g}$ poly-ICLC) there was limited E7-specific $\mathrm{T}$ cell response. In the second cohort $(500 \mu \mathrm{g}$ HSPE7 and $500 \mu \mathrm{g}$ poly-ICLC), three out of four individuals showed specific response. In the third (500 $\mu \mathrm{g}$ HSPE7 and $1000 \mu \mathrm{g}$ poly-ICLC) all four subjects responded with E7-specific response. However, in the fourth cohort (500 $\mu \mathrm{g}$ HSPE7 and $2000 \mu \mathrm{g}$ poly-ICLC) only two of five individuals had significant increases in HPV16 E7-specific T-cells from baseline, while the remaining threesubjectsof this group maintained levels of HPV16 E7-specific T-cells that were already present at baseline. It was concluded that all dose regimens were safe and well tolerated and that doses of $500 \mu \mathrm{g}$ HSPE7 and 1-2 $\mathrm{mg}$ of Poly-ICLC were appropriate for phase II studies [73]. Yet the future of such studies remains uncertain since in May 2009 Nventa was acquired by another Canadian company, Akela Pharma Inc. [74].

Another subunit protein vaccine tested in clinical trials is known as TA-CIN (Xenova Research Ltd., Cambridge, UK), a recombinant fusion protein made of HPV16 L2, E6 and E7 produced in E. coli. A double-blind and placebo controlled phase I clinical study with this protein [75] included 40 healthy women who received three escalating doses of protein $(26,128$ and $533 \mu \mathrm{g})$ by i.m. injection, without adjuvant, at 4 week intervals. Antibody responses were observed at all three doses. Specific E6 and E7 T cell and antibody responses were induced in 8 subjects vaccinated with the highest dose. In 2005, Xenova licensed TA-CIN to Cancer Research Technology (CRT) Limited, a technology transfer company owned by Cancer Research U.K A nonrandomized phase II prime-boost vaccine trial was conducted in 29 women with biopsy-proven genital intraepithelial neoplasia (27 vulvar and 2 vaginal) grade 3. Patients were vaccinated with three doses (maximum dose) of TA-CIN followed by one dose of a recombinant vaccinia virus encoding HPV16 and 18 E6/E7 (TA-HPV). Clinical responses, evaluated by serial photographs, symptoms, and biopsy analysis before and after vaccination, were seen in five women, with one complete and four partial remissions. Symptomatic improvement was reported in fifteen women [76]. Because such a prime-boost approach showed no significant advantage over single TA-HPV vaccination, the authors concluded that no further studies were planned using this protocol. Further analysis of the immune responses in the vaccinated women of both studies showed that vaccination induced L2-specific neutralizing antibodies. However, patients responded less effectively to vaccination than healthy volunteers for induction of HPV16 L2-specific antibodies, suggesting tolerance to HPV antigens in patients due to some underlying immune deficit [77].

A recombinant fusion protein containing E6 and E7 of HPV16, expressed in E. coli, was also tested in a phase I clinical trial with 42 healthy volunteers who received three i.m. doses of E6E7 protein in combination with the adjuvant Iscomatrix ${ }^{\circledR}$ [78]. All vaccinated subjects had E6E7 antibody responses and in $80 \% \mathrm{~T}$ cell responses were demonstrated [79]. Later on, $31 \mathrm{CIN}$ patients were enrolled into a randomized blinded placebo controlled dose ranging phase I trial. Antibody, DTH, and CD8 T cell responses to E6 and E7 proteins were significantly greater in the immunized subjects than in placebo recipients [80]. A reduction of viral load was detected in some patients. Follow-up studies with this protein have not been reported to date

One subunit vaccine also designed to enhance the cellular immune response to E7 contained a fusion of an HPV16 E7 mutant with the first amino acids of the Haemophilus influenzae protein D (PD-E7) in AS02B adjuvant (Adjuvant System 2B, GlaxoSmithKline), which consists of an emulsion of monophosphoryl lipid A and QS21, a saponine extract from the south American tree Quillaja saponaria Molina. In a first clinical study, five patients with HPV16 positive, histologically demonstrated severe cervical dysplasia (CIN III) received three doses of the vaccine four weeks apart (within two months) before conization (removal of the lesions) was performed. Histological analysis of the biopsies showed CD4+ and CD8 $+\mathrm{T}$ cell infiltration and a limited degree of regression [81]. In a second phase I/II clinical trial seven patients, five with CIN III and two with $\mathrm{CIN}$ I, received three i.m. injections of PD-E7/ AS02B at 2week intervals. As control, three CIN I patients received placebo. Conization and histological analysis was performed 8 weeks after vaccination. All vaccinated patients had significant E7 and PD specific IgG antibodies. Preexisting CD4+ and CD8+ responses to PD-E7 were detected in one and five patients, respectively. Five vaccinated patients showed significantly increased IFN $-\gamma \mathrm{CD} 8+\mathrm{T}$ cell responses to E7. However, clinical response was only observed in the CIN II but not in the CIN III patients [82]. The authors 
concluded that a clinical study with a larger number of patients should be carried out to further analyze the efficacy of the PD-E7/ AS02B vaccine. Nevertheless, no new studies with this vaccine have been reported to date.

\section{Dendritic Cell Vaccines}

DCs are a heterogeneous group of multifunctional antigen presenting cells (APCs) [83]. DCs present self peptide-MHC complexes to lymphoid cells in the thymus to induce $\mathrm{T}$ cell-tolerance. They also present non-self peptideMHC complexes to naïve and memory $\mathrm{T}$ cells to induce $\mathrm{T}$ cell activation from the resting or naive state into distinct classes of effector cells due to their ability to deliver costimulatory signals [84]. Upon activation with different stimuli DCs achieve maturation thereby expressing high levels of several molecules at the cell surface: early activation markers such as CD83, MHC class I and II, as well as accessory molecules like CD40, CD80, CD86.

DCs are currently being studied as adjuvants for vaccines or as a direct therapy to induce immunity against cancer in two different approaches [83, 85]: 1) DCs can be easily isolated from peripheral blood, expanded ex vivo, loaded with tumor antigens and injected back into the patient as activated autologous APCs, thus taking advantage of their ability to migrate to lymphoid organs and induce $\mathrm{T}$ cell and NK responses; and 2) tumor antigens are targeted directly to DCs using monoclonal anti-DC antibodies. An important limitation is that DCs do not proliferate and after a certain time course they undergo apoptosis being replaced by a new pool of cells. Thus, their short half life limits their ability to stimulate effective, long lasting antigen-specific $\mathrm{T}$ cell responses.

A DC based vaccine was applied to a case of HPV18+ cervical adenocarcinoma complicated with pulmonary metastases [86]. The patient received 14 consecutive doses (3-5 × $10^{6}$ cells/dose injected s.c.) of autologous DCs loaded with HPV18 E7 protein. In addition, 72 hours after the $1^{\text {st }}$, $2^{\text {nd }}$ and $4^{\text {th }}$ doses the patient received a dose of autologous $\mathrm{T}$ cells stimulated in vitro with E7-loaded DCs. Serial computer tomography scans and histological analysis of tumor biopsies carried out 10 months after the initial vaccination showed metastasis growth arrest with fibrosis and macrophage infiltration of tumors. However, metastasis growth reactivated at month 20 and the patient died three months later.

Another DC based vaccine was tested in a phase I clinical trial with 15 stage IV cervical cancer patients using monocyte-derived autologous DCs loaded with E7 protein from HPV16 or HPV18 [87]. The vaccine was well tolerated and no side effects were observed. A specific antibody response was seen in 3 subjects and $\mathrm{T}$ cell responses were detected by IFN- $\gamma$ and ELISPOT assays in 4 patients. However, no clinical responses were observed. Strong reduction or loss of HLA expression was detected in tumor biopsies of three out of four patients analyzed. The authors concluded that in future studies patients with confirmed tumor HLA expression should be selected and that boosting of immune responses by adjuvants should be introduced. In a more recent clinical study, four patients harboring recurrent/metastatic cervical cancer refractory to conventional treatment received autologous monocyte- derived DCs pulsed with recombinant HPV16 E7 or HPV18 E7 protein [88]. Three out of four patients were significantly immunocompromised before starting vaccination, as detected by DTH with various antigens. Vaccinations were followed by s.c. administration twice daily of low doses of human recombinant IL-2 $\left(1 \times 10^{6} \mathrm{IU} / \mathrm{m}^{2}\right)$ from day 3 to day 7. Specific humoral and cellular $\mathrm{CD} 4+\mathrm{T}$ cell responses to E7 were detected in 2 patients by ELISA and IFN- $\gamma$ ELISPOT assays. Increased numbers of E7-specific IFN- $\gamma$ secreting CD8 $+\mathrm{T}$ cells were detected in all patients after vaccination. In addition, a positive DTH response to the intradermal injection of HPV E7 protein and/or irradiated autologous tumor cells was detected in two patients after six vaccinations. Again, no objective clinical responses were observed, although both patients with positive DTH to the vaccine had a slower tumor progression (13 months survival from the beginning of therapy) in comparison to DTH unresponsive patients (5 months). It was concluded that treatment-induced immunosuppression in late stage cervical cancer patients may represent a severe limitation to the efficacy of DC vaccination.

\section{DNA Vaccines}

Plasmid DNA based vaccines have been shown to induce CTL and antibody responses to HPV antigens $[89,90]$. A DNA vaccine originally named ZYC101 (Zycos Inc.) consists of plasmid DNA encapsulated in biodegradable poly[lactide-co-glicolide] polymer microparticles, which should favor cell entry. The plasmid encodes a sequence of HPV-16 E7 containing several overlapping HLA-A2restricted epitopes fused to a secretory signal derived from the HLA-DRA*0101 locus [91, 92]. A phase I dose escalation clinical trial included 12 patients with anal dysplasia associated to HPV16 infection, all with HLA-A2 haplotype. The patients were vaccinated with four i.m. injections of 50-400 $\mu \mathrm{g}$ of $\mathrm{ZYC101}$ at 3-week intervals [91]. The vaccine was well tolerated at all doses tested. In 10 subjects there was increased immune response to the peptide epitopes encoded by the plasmid as demonstrated by direct ELISPOT, which continued 6 months after the initiation of therapy. Partial histological responses were observed in three patients, one receiving the 200 and two the $400 \mu \mathrm{g}$ dose. In a later phase I study 15 HLA-A2 women with HPV16 (+) CIN II or III received three doses (i.m. and s.c.) of the same vaccine at 3-week intervals, followed 4 weeks later by surgical excision [92]. E7 peptide-specific T cell responses were demonstrated in 11 patients by an IFN- $\gamma$ ELISA assay. In addition, complete regression of cervical lesions was observed in 5 patients, of whom 4 showed anti-HPV16 E2 IgA responses in cervical smears. Such immune reactivity to an HPV antigen not included in the vaccine was interpreted as lysis of infected cells caused by the $\mathrm{T}$ cell responses induced by vaccination.

A second generation of this vaccine, initially named ZYC101a, contains plasmid DNA encoding fragments derived from the E6 and E7 proteins of HPV16 and !8 formulated within polymer microparticles [93]. It was tested in a multicenter, double-blind, randomized, placebocontrolled trial which included 161 patients with biopsyconfirmed CIN II/III lesions. The patients were randomized to 3 i.m. doses of either placebo or ZYC101a (100 or 200 $\mu \mathrm{g} /$ dose). All patients underwent cervical conization six 
months after the first injection. The primary endpoint for this study was histologically confirmed resolution of the CIN. A central pathology review selected 127 patients as evaluable for efficacy. Mild to moderate adverse effects were observed at the injection site. A higher proportion of $\mathrm{ZYC101a}$ vaccinated patients resolved the CIN lesions as compared to the placebo-vaccinated group ( $43 \%$ vs $27 \%$ ), but this difference was not statistically significant $(\mathrm{P}=0.12)$. Nevertheless, in a prospectively restricted group of women younger than 25 years $(n=43)$, resolution was significantly higher in the combined ZYC101a groups compared to placebo $(70 \%$ vs $23 \% ; \mathrm{P}=0.007)$. Since $Z y \cos$ Inc. was acquired by MGI Pharma in the year 2005 ZYC101a was renamed Amolimogene. This company sponsors currently a phase II clinical trial (multi-center, double-blinded, randomized, placebo-controlled) with $288 \mathrm{CIN}$ II/III patients younger than 25 years $[72,94]$, whose completion is expected this year (ClinicalTrials.gov Identifier: NCT00264732) [95].

\section{Viral Vector Vaccines}

A number of RNA and DNA viruses have been engineered as recombinant viral vectors [96]. It is believed that future success in the field of gene therapy and cancer vaccines will be closely linked to the development of new generations of viral vectors [97]. Important advantages of viral vectors are their ability to infect a variety of cell types including DCs and their superior efficiency in transducing and expressing heterologous genes. Upon administration, the vector infects host cells and drives expression of tumor antigen, which is processed and presented as a viral antigen generating MHC class I-restricted CTL as well as humoral responses. The main limitations of viral vectors are related to safety concerns, high production costs and their stability, which requires frozen conservation.

Several vaccines based on vaccinia virus vectors designed to induce long-lasting CTL responses against HPV E2 E6 and E7 antigens are being tested in clinical trials (Table 2). This virus is highly immunogenic and causes lysis of the infected cells, which ensures uptake of HPV antigens by APCs. In addition, lysis minimizes the risk of insertional mutagenesis or other effects due to the viral proteins. The first HPV vaccine of this type was the so called TA-HPV, which carries E6/E7 genes of HPV16 and HPV18 inserted into the genome of the strain Wyeth of vaccinia virus. In both pairs of genes the stop codon of E6 was removed to create fusion E6-E7 genes. In addition a mutation was introduced in the E7 genes to inactivate the site of interaction with $\mathrm{pRb}$. This vaccine was first tested in an open label phase I/II trial in eight patients with late stage cervical cancer, who received a single dose of TA-HPV [98]. All patients reacted with anti-vaccinia antibodies and three subjects developed an HPV-specific antibody response. One patient developed an HPV-specific CTL response. No clinical response was observed. A second phase I trial included 29 patients with clinical stage Ib or IIa cervical cancer. The patients were vaccinated with TA-HPV twice $\left(2.5 \times 10^{5}\right.$ pfu by scarification) 4 weeks apart, starting 2 weeks before radical hysterectomy was carried out [99]. An HPVspecific CTL response was found in 4 patients, while 8 patients developed HPV-specific antibody responses. Again, no clinical benefit was observed. Later on, the TA-HPV vaccine was tested in a phase II study in 12 patients (aged 42-54 years) with high-grade vulvar or vaginal intraepithelial neoplasia of up to 15 years duration [100]. An increased HPV-specific T-cell response was demonstrated in 6 patients by IFN- $\gamma$ ELISPOT using pooled 22 -mer peptides spanning HPV-16 E6 and E7. Clinically, a 50\% reduction in lesion diameter in 5 patients over 24 weeks and a complete remission were observed. In a parallel phase II study, 18 women with HPV16 (+) high-grade vulvar intraepithelial neoplasia were vaccinated with a single dose of TA-HPV and their clinical and analytical status was monitored over a follow-up period of 6 months [101]. Overall, 13 patients showed an increased HPV 16-specific immune response. Of these, 8 women experienced a reduction in lesion diameter of at least 50\%. Viral load, measured before and after vaccination by real time PCR, was reduced or cleared in six of eight clinical responders but also in 6 out of 10 nonresponders. Interestingly, clinical responders had significantly higher levels of lesion-associated CD4 $(+)$, $\mathrm{CD} 8(+)$, and $\mathrm{CD} 1 \mathrm{a}(+) \mathrm{T}$ cells before vaccination, as compared with non-responders. The authors concluded that the degree of local $\mathrm{T}$ cell infiltration might be a critical factor in the development of effective responses to vaccine therapy in HPV-associated neoplasia. None of these studies were placebo-controlled. In another study by the same authors, 10 patients with HPV 16-positive high grade VIN, previously primed with TA-HPV, received three doses of TA-CIN [101]. HPV 16-specific T-cell and/or serological responses were demonstrated in 9 patients, three of whom showed lesion shrinkage or symptom relief. However, no direct correlation between clinical and immunological responses was seen.

Another vaccinia-HPV vaccine used a Modified vaccinia Ankara (MVA) virus, a highly attenuated replicationdeficient vaccinia strain, expressing the HPV16 E2 protein (MVA-E2). In a phase I/II trial 78 patients with CIN I, II or III were enrolled, of which 36 were inoculated in the uterus with six doses of MVA-E2 (10 ${ }^{7}$ virus particles/dose) at weekly intervals, while the rest were treated with cryosurgery [102]. The evolution of the lesions after vaccination was followed weekly by colposcopy and cytology analysis. In the vaccinated group, 34 out of 36 patients were reported to show complete remission, while 2 subjects showed partial remission (from CIN III to CIN I). Antibody responses to the MVA-E2, as well as specific cytotoxic responses against cancer cells bearing HPV DNA were detected in all patients in this group. The viral DNA was cleared in $50 \%$ of these patients. In the cryosurgery group the CIN lesions were removed, but the patients did not develop cytotoxic activity against cancer cells bearing HPV DNA. In later study with the MVA-E2 vaccine 34 patients with high-grade CIN were vaccinated following the same protocol [103]. Histological analysis showed complete remission of the lesions in 20 patients. Again, all vaccinated women developed HPV-specific antibody and cytotoxic responses. A control group treated surgically to eliminate the lesions did not develop cytotoxic responses against HPV. A more recent study with the MVA-E2 vaccine in men with intraurethral flat condiloma showed similar efficacy of the vaccine in clearing the lesions [104]. None of these reports informed on the immune status of the patients and whether they had HPV-specific immune responses before 
vaccination. In addition, the evolution of the lesions and their size was determined by colposcopy, which may lead to error. No placebo control was included in these two studies.

The third HPV-viral vector vaccine under clinical study is named MVA-HPV-IL2 or TG4001/R3484 (Transgene S A, Strasbourg) [105]. It is based on vaccinia MVA that was engineered to express HPV E6 and E7 proteins containing deletions in their domains interacting with p53 and pRb, respectively, as well as IL-2 to enhance innate and acquired cellular immune responses to the HPV antigens. This company disclosed of three Phase I clinical studies with TG 4001/R3484 aimed to determine the safety of the product, which was injected i.m., and to define the dose to be used in further clinical trials. Subsequently, a 6-week Phase II trial enrolled 31 patients with HPV16-related CIN II/III, of whom 29 were evaluable for vaccine efficacy. The patients were randomized into two groups, which received two different doses $\left(5 \times 10^{5} \mathrm{pfu}\right.$ and $\left.5 \times 10^{7} \mathrm{pfu}\right)$ of MVA-HPV-IL2, followed by conization six weeks after vaccination. There was some reduction in the lesion size or grade in 5 out of 19 patients vaccinated with the higher dose, as determined by histological analysis, while no responses were observed in the 12 patients inoculated with the lower dose. A second phase II trial was conducted to evaluate the efficacy of MVA-HPV-IL2 at the highest dose $\left(5 \times 10^{7} \mathrm{pfu}\right)$ in a 6-month follow up period from the first vaccination [106]. The studyenrolled 21 patients aged 25 to 44 years with HPV16 (+) CIN II/III and was carried out in nine health centres in France. All patients received three s.c. injections of MVAHPV-IL2 at the dose of $5 \times 10^{7} \mathrm{pfu}$. Cytology and virus detection analyses were performed. Transgene S.A. announced that six months after vaccination 10 women $(47,6 \%)$ had no more CIN II/III and that HPV16 E6 and E7 mRNA could not be detected in any of the responders. However, the spontaneous regression rate of CIN lesions in that age group has been estimated to be up to $46 \%$ [107]. This company entered last year into a cooperation agreement with Roche Holding A G and announced a placebocontrolled Phase III trial programme enrolling an estimated $500 \mathrm{HPV} 16(+) \mathrm{CIN}$ II/III patients in Europe and the U.S. [108].

In addition to vaccinia, a number of other virus vectors harboring HPV antigens have been tested in preclinical studies with laboratory animals, such as three genera of the Alphavirus family, namely Sindbis virus (SV), Semliki Forest virus (SFV) and the Venezuelan equine encephalitis virus (VEEV), as well as recombinant adenovirus (rAd). A SV vector vaccine was constructed encoding a fusion of HPV16 E7 and the tegument protein VP22 of herpes simplex virus type 1. VP22 should facilitate intercellular transport of E7, thus enhancing its presentation to the immune system [109]. This vaccine induced in mice CD8+ $\mathrm{T}$ cell responses that conferred protection against tumor cells expressing E7. A SFV recombinant virus used to express a fusion of the HPV16 E6 and E7 proteins elicited CTL responses and antitumor effects [110]. Vaccination with VEEV-based replicon particles expressing HPV16 E7 induced class Irestricted $\mathrm{CD} 8+\mathrm{T}$ cell responses, leading to regression of established tumors in $67 \%$ of tumor bearing mice and prevented tumor development in all vaccinated mice [111]. Further, the same vector encoding a fusion of the HPV16 E6 and E7 proteins protected $100 \%$ of mice from tumor development after challenge with E7-expressiong TC-1 tumor cells [112]. An experimental vaccine based on rAd encoded a fusion protein composed of the hepatitis B surface antigen (HBsAg) and a non-transforming truncated mutant of the HPV16 E7 protein devoid of its pRb-binding domain [113]. Mice vaccinated with low doses of this vaccine developed E7-specific CTL and antibody responses and were protected against challenge with isogenic tumor cells harboring E7. To date, no clinical trials have been reported with any of these recombinant viruses.

Despite the great potential of replication-defective viruses as vectors, they harbor risks that limit their clinical use, such as toxicity due to unwanted viral gene expression, immune responses towards viral antigens, insertional mutagenesis or potential recombination and reversion to a replication-competent form. In addition, the development of immune responses to the vector or the existence of previous immunity against viral antigens may pose some limitations. For instance, a large proportion of the population over the age of 35 years was vaccinated with vaccinia virus during the campaigns to eradicate smallpox. Therefore, under such circumstances, immunization with vaccinia vectors may induce strong memory responses that could hinder response to the HPV antigens. A possible way to overcome this problem could be the use of protocols combining heterologous prime/boost immunizations. Thus, for instance, it has been shown that prime/boost immunization with TACIN and TA-HPV enhanced cytotoxic responses in mice [114].

\section{Ongoing Preclinical Studies}

An increasing number of experimental vaccines are being tested in laboratory animals, mostly in mice. Currently, strategies focus preferentially on the use of larger peptides or fusion proteins and the plasmids encoding them with the aim of facilitating presentation of a larger number of CTL and T helper viral epitopes. In a study with mice, immunization with a 35mer peptide derived from HPV16 E7, which contained various CTL and T helper epitopes, elicited a stronger CTL response as compared with immunization using a smaller peptide carrying a single CTL epitope [115]. In addition, studies on rabbits infected with the CRPV show that immunization with large peptides harboring CTL epitopes can induce clearance of latent infection and reduce growth of established papillomas in a significant number of animals [116]. These results support the notion that long peptides are more effective vaccines, probably because they carry several epitopes and because their presentation is more effective, as it requires processing by antigen presenting cells rather than simple binding to $\mathrm{MHC}$ molecules.

In the field of dendritic cell vaccines, efforts are being made to improve their capacity to induce CTL responses by strategies that include loading DCs with HPV peptides combined with siRNA against the transcripts of the two proapoptotic genes Bak and Bax to lengthen survival of DCs and thus amplify their immunogenic effects [117]. Another strategy used was transfection of DCs with a gene encoding a mutant shuffled E7 protein [118].

Preclinical studies with DNA vaccines comprise a wide range of strategies directed to improve antigen expression and favor presentation by MHC class I. The first has been 
achieved through optimization of the codon usage of HPV genes replacing the viral codon sequences by synthetic genes containing codons frequently used in highly expressed human genes [24, 89]. The second objective has been approached in various ways such as: (i) targeting HPV antigens to centrosomes to favor antigen presentation through MHC class I molecules [119], (ii) fusion of HPV antigens to ubiquitin to direct them to the degradation pathway $[111,120]$, (iii) fusion to calreticulin to facilitate interaction with MHC class I molecules [121], (iv) a triple fusion protein comprising an HPV16 E6 epitope, the 2microglobulin and a heavy chain of MHC class I to avoid processing of the antigen and facilitate a stable antigen presentation [122], (v) fusion to the HSV VP22 protein to enable intercellular transference of the HPV antigen and hence a broader presentation [123].

\section{CONCLUSIONS AND PERSPECTIVES}

Clinical studies indicate that prophylactic vaccines have no therapeutic effects and therefore cannot be applied to women with persistent HPV infection, who are at risk of developing cervical cancer. Indeed, prophylactic vaccines do not provide protection against progression to $\mathrm{CIN}$ induced by HPV present at the time of vaccination $[61,124]$. Therefore, millions of women already infected by HR-HPV are in need of therapies that help their immune system to clear the infection. The significant relapse rate associated with the conventional therapy of $\mathrm{CIN}$ and the high mortality associated with cervical cancer (30-40\%), together with the possibility that a successful immunotherapy strategy against HPV-associated tumors might be extrapolated to non-viral cancers, altogether warrant further attempts to develop therapeutic vaccines targeting tumor-HPV antigens. This is reflected in the large number of strategies and studies that have reached clinical trials phase I or II. Table $\mathbf{2}$ summarizes results of 19 studies, in which a total of 490 patients were enrolled. Leaving out the trials with viral vectors, a total of 14 partial and 54 complete remissions were reported out of 309 patients. Of these, 42 were obtained with DNA, 9 with protein and 3 with peptide vaccines. Among trials using Vaccinia virus as vector, the E6/E7/IL-2 vaccine gave 15 partial remissions out of 53 patients, but apparently the most successful was the BPV (bovine papillomavirus)-E2 vaccine with 11 partial and 54 complete remissions out of 70 patients studied. However, the lack of placebo controls restricts the significance of the later studies, which have also been questioned because E2 from BPV instead of HPV was used and because the vaccine was applied directly at the tumor site (intrauteral or intraurethral) [63]. An additional drawback of the vaccines based on recombinant vaccinia virus is that most people over age 35 were vaccinated with vaccinia virus against smallpox in childhood and thus may have neutralizing antibodies that hamper infection by the recombinant virus.

Despite the large number of clinical studies testing therapeutic HPV vaccines, no clear candidate vaccine for further clinical development has been identified to date. This may be explained by the intrinsic complexity of developing a product capable of stimulating the immune system to eradicate HPV-transformed cells, but also by several factors associated with the design and interpretation of clinical trials. Among these are inadequate selection and characterization of patients, small number of patients enrolled, absence of placebo controls and reluctance to perform double-blind studies. In the few studies in which patients with advanced cervical cancer were enrolled, the results showed limited efficacy, although the same vaccine had shown previously its ability to eradicate established HPV-bearing tumors in mice. The lack of correlation between mouse and human outcome is likely due to the more complex situation in natural infection, which progress through pre-neoplastic stages (Fig. 4) that may persist one to two decades before invasive cancer develops. This gives the virus time enough to adapt to the various barriers posed by the host's immune system and persist awaiting the occasion when tumor surveillance is compromised and the mechanisms of cellular immunity are down (Fig. 4). Therefore, future clinical trials to determine the efficacy of therapeutic vaccines should preferably enroll patients with precancerous lesions or early stage cervical cancer rather than patients in advanced stages of the disease. Ideally, factors like for instance MHC class I expression and antigen presenting capability by tumor cells, and the levels of MICA/MICB shedding from the tumor, should be carefully assessed to better select and evaluate the patients with respect to their suitability for immunotherapy trials.

\section{ACKNOWLEDGEMENTS}

I gratefully acknowledge Victoria Juarez for critical reading of the manuscript, Professor zur Hausen for support and advice, and Dr. J-Y Sgro and Dr. J. Doorbar for permission to reproduce Figs. 1 and 2, respectively.

\begin{tabular}{|c|c|}
\hline \multicolumn{2}{|c|}{ ABBREVIATIONS } \\
\hline AIN & $=$ Anal intraepithelial neoplasia \\
\hline $\mathrm{APC}$ & $=$ Antigen presenting cells \\
\hline $\mathrm{BCG}$ & $=$ Mycobacterium bovis bacillus Calmette-Guerin \\
\hline CIN & $\begin{array}{l}=\text { Cervical intraepithelial neoplasia (grades I, II } \\
\text { or III) }\end{array}$ \\
\hline CRPV & $=$ Cottontail rabbit papillomavirus \\
\hline $\mathrm{CxCa}$ & $\begin{array}{l}=\text { Carcinoma of the uterine cervix, or cervical } \\
\text { cancer uteri }\end{array}$ \\
\hline $\mathrm{DC}$ & $=$ Dendritic cell \\
\hline DTH & $=$ Delayed type hypersensitivity \\
\hline GMP & $=$ Good manufacturing production \\
\hline HBsAg & $=$ Hepatitis $\mathrm{B}$ surface antigen \\
\hline $\mathrm{HPV}$ & $=$ Human Papillomavirus \\
\hline HR-HPV & $=$ High-risk HPV \\
\hline Hsp & $=$ Heat shock protein \\
\hline IFA, & Incomplete Freund's adjuvant \\
\hline IRF & $=$ Interferon regulatory factor \\
\hline $\mathrm{LC}$ & $=$ Langerhans Cells \\
\hline MICA & $\begin{aligned}= & \text { Major histocompatibility complex class I- } \\
& \text { related chain A }\end{aligned}$ \\
\hline MVA & $=$ Modified vaccinia Ankara \\
\hline NK & $=$ Natural killer \\
\hline
\end{tabular}




$$
\begin{array}{ll}
\text { PADRE } & =\text { Pan:HLA DR peptide } \\
\text { PBMC } & =\text { Peripheral blood mononuclear cells } \\
\text { pRb } & =\text { Retinoblastoma protein } \\
\text { rAd } & =\text { Recombinant adenovirus } \\
\text { SFV } & =\text { Semliki Forest virus } \\
\text { SV } & =\text { SINDBIS virus } \\
\text { TAP } & =\text { transporter associated with antigen processing } \\
\text { TLR } & =\text { Toll-like receptor } \\
\text { TSA } & =\text { Tumor-specific antigen } \\
\text { VEEV } & =\text { Venezuelan equine encephalitis virus } \\
\text { VIN } & =\text { Vulvar intraepithelial neoplasia } \\
\text { VLP } & =\text { Virus like particle }
\end{array}
$$

\section{REFERENCES}

[1] IARC: Human Papillomaviruses, Monographs on the Evaluation of Carcinogenic Risks to Humans. 2008; [Accessed July 13, 2009]. Available from: http://monographs.iarc.fr/

[2] WHO (World Health Organization): Human papillomaviruses. 2008; [Accessed July 13, 2009]. Available from: http://www.who. $\mathrm{int} / \mathrm{vaccine}$ research/ diseases/viral cancers/en/index3.html

[3] Parkin M. Cervical cancer numbers in Europe. HPV Today 2006; 1: $1-3$.

[4] Centers for Disease Control and Prevention. Genital HPV infection: CDC Fact Sheet. 2008; [Accessed July 13, 2009]. Available from: http://www.cdc.gov/std/HPV/ STDFact-HPV.htm

[5] American Cancer Society. Detailed guide: cervical cancer: what are the key statistics about cervical cancer? Last Revised: May13, 2009; [Accessed May 18, 2009]. Available from: http://www.can cer.org/docroot/CRI/content/CRI_2_4_1X_What_are_the_key_stat istics_for_cervical_cancer_8.asp? sitearea $=$

[6] Coleman MP, Gatta G, Verdecchia A, et al. EUROCARE-3 summary: cancer survival in Europe at the end of the 20th century. Ann Oncol 2003; 14(Suppl 5): v128-49.

[7] Cid-Arregui A. Prophylactic HPV vaccines. Open Vaccine J 2009; in press.

[8] Shah KV, Howley PM. Papillomaviruses. In: Fields BN, Knipe DM, Howley PM, Eds. Virology. Philadelphia: Lippincott-Raven 1996: p. 2077.

[9] zur Hausen H. Immortalization of human cells and their malignant conversion by high risk human papillomavirus genotypes. Semin Cancer Biol 1999; 9: 405-11.

[10] Pyeon D, Lambert PF, Ahlquist P. Production of infectious human papillomavirus independently of viral replication and epithelial cell differentiation. Proc Natl Acad Sci USA 2005; 102: 9311-6.

[11] zur Hausen H. Papillomavirus infections--a major cause of human cancers. Biochim Biophys Acta 1996; 1288: F55-78.

[12] Auewarakul P, Gissmann L, Cid-Arregui A. Targeted expression of the E6 and E7 oncogenes of human papillomavirus type 16 in the epidermis of transgenic mice elicits generalized epidermal hyperplasia involving autocrine factors. Mol Cell Biol 1994; 14: 8250-8.

[13] Song S, Pitot HC, Lambert PF. The human papillomavirus type 16 E6 gene alone is sufficient to induce carcinomas in transgenic animals. J Virol 1999; 73: 5887-93.

[14] Yugawa T, Kiyono T. Molecular mechanisms of cervical carcinogenesis by high-risk human papillomaviruses: novel functions of E6 and E7 oncoproteins. Rev Med Virol 2009; 19: 97113.

[15] Doorbar J. HPV Life Cycle. 2008; [Accessed July 13, 2009]. Available from: http://www.nimr.mrc.ac.uk./virology/doorbar/ lifecycle/

[16] Bosch FX, Lorincz A, Munoz N, Meijer CJ, Shah KV. The causal relation between human papillomavirus and cervical cancer. J Clin Pathol 2002; 55: 244-65.

[17] Munoz N, Bosch FX, de Sanjose S, et al. Epidemiologic classification of human papillomavirus types associated with cervical cancer. N Engl J Med 2003; 348: 518-27.
[18] Bosch FX. Epidemiology of human papillomavirus infections: new options for cervical. cancer prevention. Salud Publica Mex 2003; 45(Suppl 3): S326-39.

[19] Bosch FX, Manos MM, Munoz N, et al. Prevalence of human papillomavirus in cervical cancer: a worldwide perspective. International biological study on cervical cancer (IBSCC) Study Group. J Natl Cancer Inst 1995; 87: 796-802.

[20] Walboomers JM, Jacobs MV, Manos MM, et al. Human papillomavirus is a necessary cause of invasive cervical cancer worldwide. J Pathol 1999; 189: 12-9.

[21] Giannini SL, Al-Saleh W, Piron H, et al. Cytokine expression in squamous intraepithelial lesions of the uterine cervix: implications for the generation of local immunosuppression. Clin Exp Immunol 1998; 113: 183-9.

[22] Kanodia S, Fahey LM, Kast WM. Mechanisms used by human papillomaviruses to escape the host immune response. Curr Cancer Drug Targets 2007; 7: 79-89.

[23] Tindle RW. Immune evasion in human papillomavirus-associated cervical cancer. Nat Rev Cancer 2002; 2: 59-65.

[24] Cid-Arregui A, Juarez V, zur Hausen H. A synthetic E7 gene of human papillomavirus type 16 that yields enhanced expression of the protein in mammalian cells and is useful for DNA immunization studies. J Virol 2003; 77: 4928-37.

[25] Natale C, Giannini T, Lucchese A, Kanduc D. Computer-assisted analysis of molecular mimicry between human papillomavirus 16 E7 oncoprotein and human protein sequences. Immunol Cell Biol 2000; 78: 580-5.

[26] Nees M, Geoghegan JM, Hyman T, Frank S, Miller L, Woodworth CD. Papillomavirus type 16 oncogenes downregulate expression of interferon-responsive genes and upregulate proliferation-associated and NF-kappaB-responsive genes in cervical keratinocytes. J Virol 2001; 75: 4283-96.

[27] Barnard P, Payne E, McMillan NA. The human papillomavirus E7 protein is able to inhibit the antiviral and anti-growth functions of interferon-alpha. Virology 2000; 277: 411-9.

[28] Park JS, Kim EJ, Kwon HJ, Hwang ES, Namkoong SE, Um SJ. Inactivation of interferon regulatory factor-1 tumor suppressor protein by HPV E7 oncoprotein. Implication for the E7-mediated immune evasion mechanism in cervical carcinogenesis. J Biol Chem 2000; 275: 6764-9.

[29] Lee SJ, Cho YS, Cho MC, et al. Both E6 and E7 oncoproteins of human papillomavirus 16 inhibit IL-18-induced IFN-gamma production in human peripheral blood mononuclear and NK cells. J Immunol 2001; 167: 497-504.

[30] Le Buanec H, Lachgar A, D'Anna R, et al. Induction of cellular immunosuppression by the human papillomavirus type 16 E7 oncogenic protein. Biomed Pharmacother 1999; 53: 323-8.

[31] Cho YS, Kang JW, Cho M, et al. Down modulation of IL-18 expression by human papillomavirus type 16 E6 oncogene via binding to IL-18. FEBS Lett 2001; 501: 139-45.

[32] Straight SW, Herman B, McCance DJ. The E5 oncoprotein of human papillomavirus type 16 inhibits the acidification of endosomes in human keratinocytes. J Virol 1995; 69: 3185-92.

[33] Brady CS, Bartholomew JS, Burt DJ, et al. Multiple mechanisms underlie HLA dysregulation in cervical cancer. Tissue Antigens 2000; 55: 401-11.

[34] Garrido F, Ruiz-Cabello F, Cabrera T, et al. Implications for immunosurveillance of altered HLA class I phenotypes in human tumours. Immunol Today 1997; 18: 89-95.

[35] Evans M, Borysiewicz LK, Evans AS, et al. Antigen processing defects in cervical carcinomas limit the presentation of a CTL epitope from human papillomavirus 16 E6. J Immunol 2001; 167: 5420-8.

[36] Arreygue-Garcia NA, Daneri-Navarro A, del Toro-Arreola A, et al. Augmented serum level of major histocompatibility complex class I-related chain A (MICA) protein and reduced NKG2D expression on NK and T cells in patients with cervical cancer and precursor lesions. BMC Cancer 2008; 8: 16.

[37] Fausch SC, Da Silva DM, Rudolf MP, Kast WM. Human papillomavirus virus-like particles do not activate Langerhans cells: a possible immune escape mechanism used by human papillomaviruses. J Immunol 2002; 169: 3242-9.

[38] Caberg JH, Hubert P, Herman L, et al. Increased migration of Langerhans cells in response to HPV16 E6 and E7 oncogene silencing: role of CCL20. Cancer Immunol Immunother 2009; 58: 39-47. 
[39] Tindle RW, Herd K, Doan T, et al. Nonspecific down-regulation of $\mathrm{CD} 8+\mathrm{T}$-cell responses in mice expressing human papillomavirus type 16 E7 oncoprotein from the keratin-14 promoter. J Virol 2001; 75: 5985-97.

[40] Konya J, Dillner J. Immunity to oncogenic human papillomaviruses. Adv Cancer Res 2001; 82: 205-38.

[41] Carter JJ, Koutsky LA, Hughes JP, et al. Comparison of human papillomavirus types 16, 18, and 6 capsid antibody responses following incident infection. J Infect Dis 2000; 181: 1911-9.

[42] Baay MF, Duk JM, Burger MP, de Bruijn HW, Stolz E, Herbrink P. Humoral immune response against proteins E6 and E7 in cervical carcinoma patients positive for human papilloma virus type 16 during treatment and follow-up. Eur J Clin Microbiol Infect Dis 1999; 18: 126-32.

[43] Ravaggi A, Romani C, Pasinetti B, et al. Correlation between serological immune response analyzed by a new ELISA for HPV16/18 E7 oncoprotein and clinical characteristics of cervical cancer patients. Arch Virol 2006; 151: 1899-916.

[44] Benton C, Shahidullah H, Hunter JAA. Human papilloma virus in the immunosuppressed. Papillomavirus 1992; 3: 23-6.

[45] Gabrilovich DI, Velders MP, Sotomayor EM, Kast WM. Mechanism of immune dysfunction in cancer mediated by immature Gr-1+ myeloid cells. J Immunol 2001; 166: 5398-406.

[46] Sheu BC, Hsu SM, Ho HN, Lien HC, Huang SC, Lin RH. A novel role of metalloproteinase in cancer-mediated immunosuppression. Cancer Res 2001; 61: 237-42.

[47] Molling JW, de Gruij1 TD, Glim J, et al. CD4(+)CD25hi regulatory T-cell frequency correlates with persistence of human papillomavirus type 16 and $\mathrm{T}$ helper cell responses in patients with cervical intraepithelial neoplasia. Int J Cancer 2007; 121: 1749-55.

[48] van der Burg SH, Piersma SJ, de Jong A, et al. Association of cervical cancer with the presence of $\mathrm{CD} 4+$ regulatory $\mathrm{T}$ cells specific for human papillomavirus antigens. Proc Natl Acad Sci USA 2007; 104: 12087-92.

[49] Stanley MA. Imiquimod and the imidazoquinolones: mechanism of action and therapeutic potential. Clin Exp Dermatol 2002; 27: 5717.

[50] Le Poole IC, Elmasri WM, Denman CJ, et al. Langerhans cells and dendritic cells are cytotoxic towards HPV16 E6 and E7 expressing target cells. Cancer Immunol Immunother 2008; 57: 789-97.

[51] Schofer H, Van Ophoven A, Henke U, Lenz T, Eul A. Randomized, comparative trial on the sustained efficacy of topical imiquimod $5 \%$ cream $v s$ conventional ablative methods in external anogenital warts. Eur J Dermatol 2006; 16: 642-8.

[52] van Poelgeest MI, van Seters M, van Beurden M, et al. Detection of human papillomavirus (HPV) 16-specific CD4+ T-cell immunity in patients with persistent HPV16-induced vulvar intraepithelial neoplasia in relation to clinical impact of imiquimod treatment. Clin Cancer Res 2005; 11: 5273-80.

[53] Doorbar J. Papillomavirus life cycle organization and biomarker selection. Dis Markers 2007; 23: 297-313.

[54] Nguyen CL, Eichwald C, Nibert ML, Munger K. Human papillomavirus type $16 \mathrm{E} 7$ oncoprotein associates with the centrosomal component gamma-tubulin. J Virol 2007; 81: 1353343.

[55] Ressing ME, Sette A, Brandt RM, et al. Human CTL epitopes encoded by human papillomavirus type 16 E6 and E7 identified through in vivo and in vitro immunogenicity studies of HLAA*0201-binding peptides. J Immunol 1995; 154: 5934-43.

[56] Alexander M, Salgaller ML, Celis E, et al. Generation of tumorspecific cytolytic T lymphocytes from peripheral blood of cervical cancer patients by in vitro stimulation with a synthetic human papillomavirus type 16 E7 epitope. Am J Obstet Gynecol 1996; 175: 1586-93.

[57] Khleif SN, DeGregori J, Yee CL, et al. Inhibition of cyclin DCDK4/CDK6 activity is associated with an E2F-mediated induction of cyclin kinase inhibitor activity. Proc Natl Acad Sci USA 1996; 93: 4350-4.

[58] Sano T, Oyama T, Kashiwabara K, Fukuda T, Nakajima T. Expression status of p16 protein is associated with human papillomavirus oncogenic potential in cervical and genital lesions. Am J Pathol 1998; 153: 1741-8.

[59] von Knebel Doeberitz M. New markers for cervical dysplasia to visualise the genomic chaos created by aberrant oncogenic papillomavirus infections. Eur J Cancer 2002; 38: 2229-42.
[60] Ordi J, Garcia S, del Pino M, et al. p16 INK4a immunostaining identifies occult CIN lesions in HPV-positive women. Int $\mathbf{J}$ Gynecol Pathol 2009; 28: 90-7.

[61] Hildesheim A, Herrero R, Wacholder S, et al. Effect of human papillomavirus 16/18 L1 viruslike particle vaccine among young women with preexisting infection: a randomized trial. JAMA 2007; 298: 743-53.

[62] Markowitz LE, Dunne EF, Saraiya M, Lawson HW, Chesson H, Unger ER. Quadrivalent human papillomavirus vaccine: recommendations of the advisory committee on immunization practices (ACIP). MMWR Recomm Rep 2007; 56: 1-24.

[63] Kanodia S, Da Silva DM, Kast WM. Recent advances in strategies for immunotherapy of human papillomavirus-induced lesions. Int $\mathrm{J}$ Cancer 2008; 122: 247-59.

[64] Steller MA, Gurski KJ, Murakami M, et al. Cell-mediated immunological responses in cervical and vaginal cancer patients immunized with a lipidated epitope of human papillomavirus type 16 E7. Clin Cancer Res 1998; 4: 2103-9.

[65] Alexander J, Sidney J, Southwood S, et al. Development of high potency universal DR-restricted helper epitopes by modification of high affinity DR-blocking peptides. Immunity 1994; 1: 751-61.

[66] Diamond DJ, York J, Sun JY, Wright CL, Forman SJ. Development of a candidate HLA A*0201 restricted peptide-based vaccine against human cytomegalovirus infection. Blood 1997; 90: 1751-67.

[67] van Driel WJ, Ressing ME, Kenter GG, et al. Vaccination with HPV16 peptides of patients with advanced cervical carcinoma: clinical evaluation of a phase I-II trial. Eur J Cancer 1999; 35: 94652.

[68] Muderspach L, Wilczynski S, Roman L, et al. A phase I trial of a human papillomavirus (HPV) peptide vaccine for women with high-grade cervical and vulvar intraepithelial neoplasia who are HPV 16 positive. Clin Cancer Res 2000; 6: 3406-16.

[69] Goldstone SE, Palefsky JM, Winnett MT, Neefe JR. Activity of HspE7, a novel immunotherapy, in patients with anogenital warts. Dis Colon Rectum 2002; 45: 502-7.

[70] Stressgen Biotechnologies and Roche announce global development and marketing collaboration for the treatment of human papillomavirus (HPV) with HspE7 fusion product. 2002; [Accessed October 14, 2009]Available from: http://www.prnews wire.co.uk/cgi/release? $\mathrm{id}=87078$

[71] Stressgen Biotechnologies reports HSPE7results from two clinical trials. 2004; [Accessed October 14, 2009]. Available from: http://www.secinfo.com/d11 MXs.15g2.d.htm

[72] McNeil C. Search for HPV treatment vaccine heats up, researchers optimistic. J Natl Cancer Inst 2006; 98: 954-5.

[73] Nventa Corp. Nventa announces additional positive immunological data from hspe7 phase 1 cervical dysplasia trial. 2008; [Accessed July 13, 2009]. Available from: http://www.nventacorp.com/

[74] Akela and Nventa announce closing of merger. May 2009; [Accessed July 13, 2009]. Available from: http://www.newswire. ca/en/releases/archive/May 2009/22/c6505.html

[75] de Jong A, O'Neill T, Khan AY, et al. Enhancement of human papillomavirus (HPV) type 16 E6 and E7-specific T-cell immunity in healthy volunteers through vaccination with TA-CIN, an HPV16 L2E7E6 fusion protein vaccine. Vaccine 2002; 20: 3456-64.

[76] Fiander AN, Tristram AJ, Davidson EJ, et al. Prime-boost vaccination strategy in women with high-grade, noncervical anogenital intraepithelial neoplasia: clinical results from a multicenter phase II trial. Int J Gynecol Cancer 2006; 16: 1075-81.

[77] Gambhira R, Gravitt PE, Bossis I, Stern PL, Viscidi RP, Roden RB. Vaccination of healthy volunteers with human papillomavirus type 16 L2E7E6 fusion protein induces serum antibody that neutralizes across papillomavirus species. Cancer Res 2006; 66: 11120-4.

[78] Stewart TJ, Drane D, Malliaros J, et al. ISCOMATRIX adjuvant: an adjuvant suitable for use in anticancer vaccines. Vaccine 2004; 22: 3738-43.

[79] Barnden M, Papalia L, Davis R, et al. Antigen-specific CD4+ and CD8+ T cell responses to HPV16 E6E7 ISCOMATRIX ${ }^{\mathrm{R}}$ vaccine in healthy volunteers. Mexico DF: Presentado en la 21 Conferencia Internacional de Papilomavirus 2004.

[80] Frazer IH, Quinn M, Nicklin JL, et al. Phase 1 study of HPV16specific immunotherapy with E6E7 fusion protein and ISCOMATRIX adjuvant in women with cervical intraepithelial neoplasia. Vaccine 2004; 23: 172-81. 
[81] Simon P, Buxant F, Hallez S, et al. Cervical response to vaccination against HPV16 E7 in case of severe dysplasia. Eur J Obstet Gynecol Reprod Biol 2003; 109: 219-23.

[82] Hallez S, Simon P, Maudoux F, et al. Phase I/II trial of immunogenicity of a human papillomavirus (HPV) type 16 E7 protein-based vaccine in women with oncogenic HPV-positive cervical intraepithelial neoplasia. Cancer Immunol Immunother 2004; 53: 642-50.

[83] Steinman RM. Dendritic cells: understanding immunogenicity. Eur J Immunol 2007; 37(Suppl 1): S53-60.

[84] Banchereau J, Steinman RM. Dendritic cells and the control of immunity. Nature 1998; 392: 245-52.

[85] O'Neill DW, Adams S, Bhardwaj N. Manipulating dendritic cell biology for the active immunotherapy of cancer. Blood 2004; 104: $2235-46$

[86] Santin AD, Bellone S, Gokden M, Cannon MJ, Parham GP. Vaccination with HPV-18 E7-pulsed dendritic cells in a patient with metastatic cervical cancer. N Engl J Med 2002; 346: 1752-3.

[87] Ferrara A, Nonn M, Sehr P, et al. Dendritic cell-based tumor vaccine for cervical cancer II: results of a clinical pilot study in 15 individual patients. J Cancer Res Clin Oncol 2003; 129: 521-30.

[88] Santin AD, Bellone S, Palmieri M, et al. HPV16/18 E7-pulsed dendritic cell vaccination in cervical cancer patients with recurrent disease refractory to standard treatment modalities. Gynecol Oncol 2006; 100: 469-78.

[89] Eiben GL, da Silva DM, Fausch SC, Le Poole IC, Nishimura MI, Kast WM. Cervical cancer vaccines: recent advances in HPV research. Viral Immunol 2003; 16: 111-21.

[90] Hung CF, Monie A, Alvarez RD, Wu TC. DNA vaccines for cervical cancer: from bench to bedside. Exp Mol Med 2007; 39: 679-89.

[91] Klencke B, Matijevic M, Urban RG, et al. Encapsulated plasmid DNA treatment for human papillomavirus 16-associated anal dysplasia: a Phase I study of ZYC101. Clin Cancer Res 2002; 8: 1028-37

[92] Sheets EE, Urban RG, Crum CP, et al. Immunotherapy of human cervical high-grade cervical intraepithelial neoplasia with microparticle-delivered human papillomavirus 16 E7 plasmid DNA. Am J Obstet Gynecol 2003; 188: 916-26.

[93] Garcia F, Petry KU, Muderspach L, et al. ZYC101a for treatment of high-grade cervical intraepithelial neoplasia: a randomized controlled trial. Obstet Gynecol 2004; 103: 317-26.

[94] MGIPharma I. ClinicalTrials.com: a study of amolimogene (ZYC101a) in patients with high grade cervical intraepithelial lesions of the uterine cervix. 2008.

[95] Alvarez-Salas LM. Amolimogene bepiplasmid, a DNA-based therapeutic encoding the E6 and E7 epitopes from HPV, for cervical and anal dysplasia. Curr Opin Mol Ther 2008; 10: 622-8.

[96] Cid-Arregui A, Garcia-Carranca A, Eds. Viral vectors: basic science and gene therapy. BioTechniques Books. Natick (MA): Eaton Publishing Co 2000.

[97] Oldstone MB, Levine AJ. Virology in the next millennium. Cell 2000; 100: 139-42.

[98] Borysiewicz LK, Fiander A, Nimako M, et al. A recombinant vaccinia virus encoding human papillomavirus types 16 and 18, E6 and E7 proteins as immunotherapy for cervical cancer. Lancet 1996; 347: 1523-7.

[99] Kaufmann AM, Stern PL, Rankin EM, et al. Safety and immunogenicity of TA-HPV, a recombinant vaccinia virus expressing modified human papillomavirus (HPV)-16 and HPV-18 E6 and E7 genes, in women with progressive cervical cancer. Clin Cancer Res 2002; 8: 3676-85.

[100] Baldwin PJ, van der Burg SH, Boswell CM, et al. Vacciniaexpressed human papillomavirus 16 and 18 e6 and e7 as a therapeutic vaccination for vulval and vaginal intraepithelial neoplasia. Clin Cancer Res 2003; 9: 5205-13.

[101] Davidson EJ, Boswell CM, Sehr P, et al. Immunological and clinical responses in women with vulval intraepithelial neoplasia vaccinated with a vaccinia virus encoding human papillomavirus 16/18 oncoproteins. Cancer Res 2003; 63: 6032-41.

[102] Corona Gutierrez CM, Tinoco A, Navarro T, et al. Therapeutic vaccination with MVA E2 can eliminate precancerous lesions (CIN 1, CIN 2, and CIN 3) associated with infection by oncogenic human papillomavirus. Hum Gene Ther 2004; 15: 421-31.

[103] Garcia-Hernandez E, Gonzalez-Sanchez JL, Andrade-Manzano A, et al. Regression of papilloma high-grade lesions (CIN 2 and CIN 3) is stimulated by therapeutic vaccination with MVA E2 recombinant vaccine. Cancer Gene Ther 2006; 13: 592-7.

[104] Albarran YCA, de la Garza A, Cruz Quiroz BJ, et al. MVA E2 recombinant vaccine in the treatment of human papillomavirus infection in men presenting intraurethral flat condyloma: a phase I/II study. BioDrugs 2007; 21: 47-59.

[105] Trangene SA: TG 4001 (MVA-HPV-IL2). 2008; [Accessed July 13, 2009]. Available from: http://www.transgene.fr/us/product pipeline/iframe mva hpv il2.htm

[106] Brun J-L. In a phase ii study with hpv16 cin2/3 patients, transgene's tg4001 induces clinical regression and hpv16 transcription inhibition. EUROGIN. Paris: 6th International Multidisciplinary Congress 2006.

[107] Chan JK, Monk BJ, Brewer C, et al. HPV infection and number of lifetime sexual partners are strong predictors for 'natural' regression of CIN 2 and 3. Br J Cancer 2003; 89: 1062-6.

[108] Trangene: First Half 2009 Results. TG4001/R3484 (MVA-HPVIL2): targeted immunotherapy for the treatment of HPV-induced cervical diseases. 2009; [Accessed October 14, 2009]. Available from: http://www.evaluate pharma.com/Universal/View.aspx?type $=$ Story\&id $=194271$

[109] Cheng WF, Hung CF, Hsu KF, et al. Cancer immunotherapy using Sindbis virus replicon particles encoding a VP22-antigen fusion. Hum Gene Ther 2002; 13: 553-68

[110] Daemen T, Riezebos-Brilman A, Bungener L, Regts J, Dontje B, Wilschut J. Eradication of established HPV16-transformed tumours after immunisation with recombinant Semliki Forest virus expressing a fusion protein of E6 and E7. Vaccine 2003; 21: 10828.

[111] Velders MP, McElhiney S, Cassetti MC, et al. Eradication of established tumors by vaccination with Venezuelan equine encephalitis virus replicon particles delivering human papillomavirus 16 E7 RNA. Cancer Res 2001; 61: 7861-7.

[112] Cassetti MC, McElhiney SP, Shahabi V, et al. Antitumor efficacy of Venezuelan equine encephalitis virus replicon particles encoding mutated HPV16 E6 and E7 genes. Vaccine 2004; 22: 520-7.

[113] Baez-Astua A, Herraez-Hernandez E, Garbi N, et al. Low-dose adenovirus vaccine encoding chimeric hepatitis B virus surface antigen-human papillomavirus type 16 e 7 proteins induces enhanced e7-specific antibody and cytotoxic T-cell responses. J Virol 2005; 79: 12807-17.

[114] van der Burg SH, Kwappenberg KM, O'Neill T, et al. Pre-clinical safety and efficacy of TA-CIN, a recombinant HPV16 L2E6E7 fusion protein vaccine, in homologous and heterologous primeboost regimens. Vaccine 2001; 19: 3652-60.

[115] Zwaveling S, Ferreira Mota SC, Nouta J, et al. Established human papillomavirus type 16-expressing tumors are effectively eradicated following vaccination with long peptides. J Immunol 2002; 169: 350-8.

[116] Vambutas A, Devoti J, Nouri M, et al. Therapeutic vaccination with papillomavirus E6 and E7 long peptides results in the control of both established virus-induced lesions and latently infected sites in a pre-clinical cottontail rabbit papillomavirus modell. Vancouver, Canada: 22nd International Papillomavirus Conference 2005.

[117] Peng JC, Thomas R, Nielsen LK. Generation and maturation of dendritic cells for clinical application under serum-free conditions. J Immunother 2005; 28: 599-609.

[118] Ohlschlager P, Pes M, Osen W, et al. An improved rearranged Human Papillomavirus Type 16 E7 DNA vaccine candidate (HPV$16 \mathrm{E} 7 \mathrm{SH}$ ) induces an $\mathrm{E} 7$ wildtype-specific $\mathrm{T}$ cell response. Vaccine 2006; 24: 2880-93.

[119] Hung CF, Cheng WF, He L, et al. Enhancing major histocompatibility complex class I antigen presentation by targeting antigen to centrosomes. Cancer Res 2003; 63: 2393-8.

[120] Liu Y, Chiriva-Internati M, Grizzi F, et al. Rapid induction of cytotoxic T-cell response against cervical cancer cells by human papillomavirus type 16 E6 antigen gene delivery into human dendritic cells by an adeno-associated virus vector. Cancer Gene Ther 2001; 8: 948-57.

[121] Peng S, Ji H, Trimble C, et al. Development of a DNA vaccine targeting human papillomavirus type 16 oncoprotein E6. J Virol 2004; 78: 8468-76.

[122] Huang CH, Peng S, He L, et al. Cancer immunotherapy using a DNA vaccine encoding a single-chain trimer of MHC class I linked 
to an HPV-16 E6 immunodominant CTL epitope. Gene Ther 2005; 12: $1180-6$.

[123] Hung CF, He L, Juang J, Lin TJ, Ling M, Wu TC. Improving DNA vaccine potency by linking Marek's disease virus type 1 VP22 to an antigen. J Virol 2002; 76: 2676-82.
[124] The FUTUREII Study Group: quadrivalent vaccine against human papillomavirus to prevent high-grade cervical lesions. N Engl J Med 2007; 356: 1915-27.

[125] Modis Y, Trus BL, Harrison SC. Atomic model of the papillomavirus capsid. EMBO J 2002; 21: 4754-62.

[126] Ressing ME, van Driel WJ, Brandt RM, et al. Detection of T helper responses, but not of human papillomavirus-specific cytotoxic $T$ lymphocyte responses, after peptide vaccination of patients with cervical carcinoma. J Immunother 2000; 23: 255-66.

Received: July 21, 2009

Revised: August 11, 2009

Accepted: August 20, 2009

(c) Angel Cid-Arregui; Licensee Bentham Open.

This is an open access article licensed under the terms of the Creative Commons Attribution Non-Commercial License (http: //creativecommons.org/licenses/by-nc/

3.0/) which permits unrestricted, non-commercial use, distribution and reproduction in any medium, provided the work is properly cited. 